\title{
IN-PHASE INTER-HEMISPHERIC CHANGES IN TWO UPWELLING REGIONS: THE SOUTHEAST BRAZILIAN AND NW IBERIAN MARGINS
}

\begin{abstract}
Renata Hanae Nagai ${ }^{1}$, Maria Virgínia Alves Martins ${ }^{2,3}$, Leticia Burone ${ }^{4}$, Ilana Elazari Klein Coaracy Wainer ${ }^{1}$, Silvia Helena de Mello e Sousa ${ }^{1}$, Rubens Cesar lopes Figueira ${ }^{1}$, MárCia Caruso Bícego ${ }^{1}$, Daniel Pavani Vicente Alves ${ }^{1}$, João Manuel Alveirinho Dias ${ }^{5}$ and Michel Michaelovitch De MahiQues ${ }^{1, *}$
\end{abstract}

1 Instituto Oceanográfico, Universidade de São Paulo, Praça do Oceanográfico, 191, 05508-900, São Paulo, SP, Brazil, renatanagai@usp.br; wainer@usp.br; smsousa@usp.br, rfigueira@usp.br; marciacbicego@gmail.com; pavani@saltambiental.com.br; mahiques@gmail.com

2 Universidade do Estado do Rio de Janeiro (UERJ), Faculdade de Geologia, Departamento de Estratigrafia e Paleontologia. Av. São Francisco Xavier, 524, sala 2020A, Maracanã, 20550-013, Rio de Janeiro, RJ, Brazil, virginia.martins@ua.pt

3 Geobiotec, Universidade de Aveiro, Departamento de Geociências, Campus de Santiago, 3810-193, Aveiro, Portugal.

4 Facultad de Ciencias, Universidad de la Republica, Montevideo, Uruguay, lburone@usp.br

5 Centro de Investigação Marinha e Ambiental (CIMA), Universidade do Algarve, Campus de Gambelas, Faro, Portugal. jdias@ualg.pt

*Corresponding Author, mahiques@usp.br

Received on 30 December 2015

Received in revised form on 21 January 2016

Accepted on 04 February 2016

Editor:

Herminio Ismael de Araújo-Júnior, Universidade do Estado do Rio de Janeiro,

Brazil
Citation:

Nagai, R., Martins, M.V.A., Burone, L., Wainer, I.E.K.C., Mello-e-Sousa, S.H., Figueira, R.C.L., Bícego, M.C., Alves, D.P.V., Dias, J.M.A., Mahiques, M.M., 2016. In-phase inter-hemispheric changes in two upwelling regions: The Southeast Brazilian and NW Iberian margins. Journal of Sedimentary Environments, 1(1): 4367.

\section{Abstract}

Two high-resolution multi-proxy records from cores collected in the upwelling regions off Cabo Frio (Brazil, core 7620) and Galicia (NW Iberian Peninsula, core KSGX40) were used to evaluate environmental changes during the Holocene. Core 7620 is a muddy sequence that exhibits gradual coarsening upward and covers a time period of approximately $9400 \mathrm{yr}$ cal BP. Core KSGX40 records the last $4800 \mathrm{yr}$ cal BP and consists of a sedimentary sequence exhibiting gradual fining upward in grain size. Results from core 7620 indicate that important changes occurred at 7000, 5800 and $3000 \mathrm{yr}$ cal BP. Micropaleontological proxies indicate an increase in organic carbon supply towards the bottom, due to higher oceanic productivity, in the last 2500 yr cal BP. This increment in oceanic productivity is likely related to stronger upwelling events in the Cabo Frio region in that period. Core KSGX40 also indicates an increment in upwelling events in the Galicia region in the last $2500 \mathrm{yr}$ cal BP. In both systems, the upwelling is linked to the intensification of $\mathrm{NE}$ winds and the prevalence of relatively drier climatic conditions. The Holocene upwelling changes in the Cabo Frio region were previously attributed to deviations in the position of the Inter-Tropical Convergence Zone (ITCZ), whereas in the Galician area this phenomenon was attributed to alterations in the North Atlantic Oscillation (NAO). The multi-millennial variability recorded in both cores suggests the occurrence of Holocene in-phase climatic changes both in Southern Hemisphere at the latitudes of the SW coast of Brazil (Cabo Frio region) and in the Northern Hemisphere, at the latitude of Galicia (NW Iberian Margin). These coupled climatic alterations were probably related to changes in the oceanic-atmospheric climatic systems, coupled with and amplified by solar forcing effects.

Keywords: Holocene. Paleoceanography. Atlantic Ocean. Inter-Hemispheric. Upwelling. Continental Shelf 


\section{Introduction}

The Holocene is considered to have been a relatively stable climatic period in Earth's history. However, this epoch is marked by seasonal climate variability derived from the interplay of several factors of high complexity (Moros et al., 1997; Moy et al., 2002; Solomon et al., 2007; Wanner et al., 2008) that have been recognized in many paleoclimatic and paleoceanographic records from different regions based on continental (e.g., Thompson et al., 1995; Tarasov et al., 1998, 2000; Claussen et al., 1999; Wang et al., 2001) and marine records (e.g., Pflaumann, 1980; Rohling and De Rijk, 1999; Barron et al., 2004; Álvarez et al., 2005). Changes within these records seems to be characterized by interhemispheric and/or global connections (Shulmeister et al., 2006) that are associated with different time scales of climatic modes of variability (Moy et al., 2002).

Ice-cores and marine and terrestrial records have suggested that a millennial-scale mode of variability predominated during the Holocene (O'Brien et al., 1995; Bond et al., 1997; Yiou et al., 1997), particularly in the Northern Hemisphere. The North Atlantic Oscillation (NAO), which significantly influences climatic conditions in the whole North Atlantic region and causes annual/decadal variability (Marshall et al., 1997; Hurrell et al., 2003), may also have triggered large-scale climate changes during the Holocene, such as multidecadal (D'Arrigo et al., 1996), centennial and millennial fluctuations (Diz et al., 2002; Álvarez et al., 2005; Bartels-Jónsdóttir et al., 2006; Martins et al., 2007, 2012). These variations are demonstrated in both atmospheric and oceanic record proxies (Bianchi and McCave, 1999; Mayewski et al., 2004).

The NAO is related to the varying strength of two atmospheric pressure systems lying over the subpolar (Icelandic Low) and subtropical (Azores High) regions of the North Atlantic (Wanner et al., 2001). The measure for this variation, the NAO Index, becomes positive in stronger phases that have a high pressure gradient, and negative in phases with a weaker pressure gradient (Hurrell et al., 2003). The pressure anomalies expressed by the NAO Index influence the transport of moisture and mild air through the Westerlies from the SE Atlantic towards Europe; cause changes in temperature, precipitation and storminess over Europe (Hurrell and Dickson, 2004); and induce alterations in sea surface temperatures (SST), surface currents (Rodwell et al., 1999) and marine productivity (Parsons and Lear, 2001).

The South Atlantic Subtropical Dipole index (SASD), based on the distribution of SST, represents the dominant mode of variability of SST. It is modulated by changes in the position and intensity of the South Atlantic Subtropical High. These changes induced alterations in the precipitation regime over South America during cold events in the Northern Hemisphere at 12.9-11.6 kyr BP and 8.6-8.0 kyr BP (Wainer et al., 2014).

In the Southern Hemisphere, various records have shown Holocene paleoclimatic changes associated with alterations in the intensity and periodicity of events such as the El Niño-Southern Oscillation (ENSO) (Bender et al., 2013) and with changes in the South American Monsoon System (SAMS) and the Southern Westerly Wind Belt (Razik et al., 2013).

A 16-year-long time-series of temperature and hydrological balance in corals from the Great Barrier Reef encompassing the last $5370 \mathrm{yr}$ cal BP revealed that ENSO, or its teleconnections to Australia, were substantially different in the mid-Holocene compared to the present (Gagan et al., 1998). Mid-Holocene changes in ENSO variability have also been cited in records from South America (e.g., Sandweiss et al., 1996; Rodbell et al., 1999; Bender et al., 2013).

In general, it seems that the climate of the Holocene in South America has been characterized as transitional (between dry and wet conditions) because of variations in the wind regime (Ledru et al., 1996, 1998; Behling, 1997, 1998; Gaiero et al., 2004; Gilli et al., 2005). At low latitudes, the movement of the ITCZ towards the equator could have been related to a decrease in solar activity (Versteegh, 2005), which explains changes in humidity. Cruz et al. (2009) proposed orbital-forcing variations along the Holocene to explain an antiphase behavior in precipitation between Northeast and Southeast South America. Based on a palynological record from the Atlantic rainforest, Garcia et al. (2004) reported paleoclimatic changes in the period between 9720 and $1950 \mathrm{yr}$ cal BP and correlated the changes with the displacement of the ITCZ and the possible occurrence of ENSO-like events.

Marine sediments under the influence of upwelling phenomena show particular features that differentiate them from sediments from other areas with hydrodynamic regimes (Diester-Haass, 1978; Thiede and Suess, 1983), providing an example of the average structure of an upwelling zone (Margalef, 1978).

Thus, the sedimentary record of oceanic productivity allows the identification of changes in the onset and intensity of wind-driven coastal upwelling systems during the Holocene. 


\subsection{The main aims of this work}

The main goal of this work is to compare the late Holocene evolution of two upwelling systems, one located in the SW Atlantic margin off Cabo Frio, Brazil (Southern Hemisphere) and the other in the NE Atlantic margin off Vigo, NW Spain (Northern Hemisphere) using highresolution, multi-proxy analyses of two sediment cores. Grain size, geochemical and benthic foraminifera data were the main parameters evaluated in this multi-proxy study. These data are integrated to reconstruct paleoenvironmental conditions, such as ocean circulation, productivity and continental rainfall changes, and to explain the climatic evolution in the South American Margin and the NW Iberian Margin, during the Holocene.

The Cabo Frio region was selected for this study because it is one of the most suitable regions for determining Holocene environmental changes in the SE South American Margin, given its wind-driven upwelling process and relatively high sedimentation rates (Mahiques et al., 2004, 2005, 2011). The NW Iberian Margin is the northernmost limit of the Eastern North Atlantic upwelling system, also known as the Canary Upwelling System (Barton et al., 1998). Variations in the signatures of upwelling processes can be used as a reliable approach to determining paleoclimatic changes during the Holocene, along the Cabo Frio and Galician continental shelves.

\subsection{Study areas}

\subsubsection{Cabo Frio region}

The Cabo Frio region represents a break in the SE South American coastline and marks the limit between two distinct oceanographic, physiographic and sedimentary provinces of the SW Atlantic margin (Fig. 1a). North of Cabo Frio, the continental shelf presents a predominant N-S orientation, carbonatic sedimentation and few rivers to furnish local terrigenous supply. The warm and salty Tropical Water transported by the Brazil Current at surface levels maintains carbonate production and preservation. South of Cabo Frio, the continental shelf is characterized by an arc-shaped feature known as the São Paulo Bight (Zembruscki, 1979), and the sedimentation is mainly terrigenous.

Descriptive studies of the Cabo Frio coastal upwelling process have been published in the literature since the South Atlantic Meteor Expedition during the 1920s (Böhnecke,
1936; Emilsson 1959, 1961; Silva and Rodrigues, 1966; Ikeda et al., 1974; Miranda and Castro, 1979). Seasonal and decadal changes in the intensity of the Cabo Frio upwelling system have been attributed to variations in wind regime, with $\mathrm{E}$ $\mathrm{NE}$ winds favoring and S-SW winds inhibiting the upwelling. The consequences of coastal upwelling in local primary productivity have also been investigated (Valentin, 1984a, b; González-Rodriguez, 1990; Campos et al., 2000).

The modern coastal upwelling-downwelling process is presented in the literature as a quasi-seasonal phenomenon (Castro and Miranda, 1998). The change in coastline at approximately $23^{\circ} \mathrm{S}$ aligns the Cabo Frio margin with the direction of the dominant $\mathrm{NE}$ trade winds during the austral summer season. According to the Ekman dynamics, a combination of these factors causes coastal water to be displaced toward the ocean and prevents the penetration of Tropical Water onto the shelf. Consequently, the cold and nutrient-enriched waters of the South Atlantic Central Water advance onto the inner shelf close to the ocean bottom and eventually upwell to the surface near the coast. A constant direction of wind over time is the most effective and intense phenomenon capable of generating this effect. As the sealevel is reduced near the coast and the thermocline rises in response to costal water offshore motion, the pressure gradient drives a geostrophically balanced coastal current alongshore that carries the upwelled waters toward the southern portions of the São Paulo Bight. The downwelling phase is associated with the passage of cold fronts across the area, in which the wind reverses from NE to SW, and which occurs most commonly during austral winters. The surface Ekman transport, composed of Tropical Water toward the coast, causes the oceanic thermocline to retract towards the open ocean.

\subsubsection{Galician region}

The studied area is characterized by a N-S coastline trend intersected by several rias that comprise the Galician Rias Baixas. Because of its strong hydrodynamism, the adjacent shelf is predominantly covered by sandy deposits (Dias and Nittrouer, 1984), with a muddy deposit known as the Galicia Mud Deposit (or Galicia Mud Patch; Dias et al., 2002b; Jouanneau et al., 2002) located at water depths of approximately $100-120 \mathrm{~m}$, formed primarily by hydrographical conditions (Dias et al., 2002a, b). This muddy area is dominated $(>50 \%)$ by fines $(<63 \mu \mathrm{m})$ composed by terrigenous sediment particles provided by the Minho river discharge ( $N$ Portugal, located at south of this area) during episodic storm events (Dias et al., 2002a, b) (Fig. 1b). 

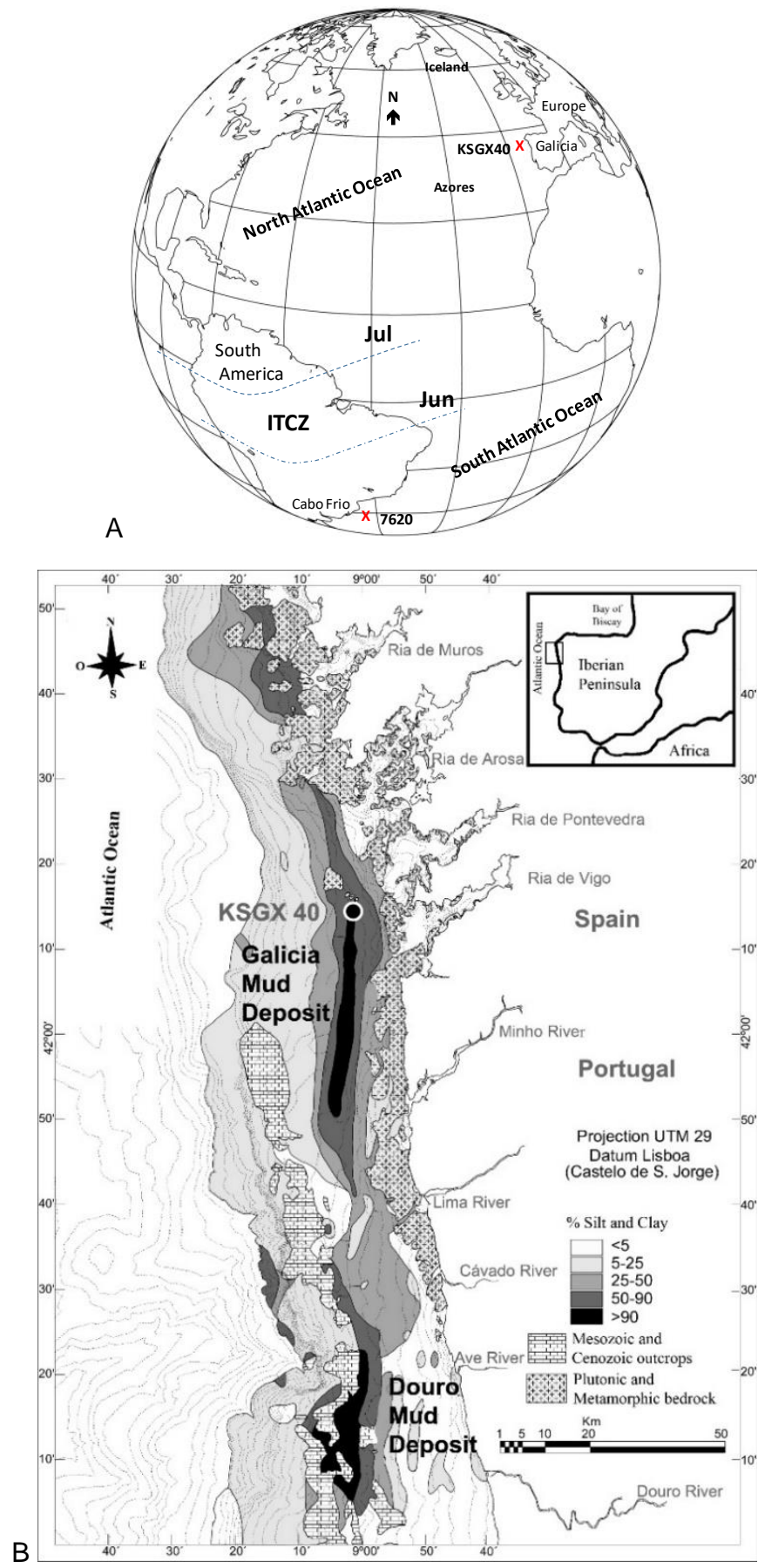

Fig. 1. A) Location of the cores 7620 and KSGX 40 (adapted from Bruce Jones Design Inc.). B) Position of core KSGX 40 in Galicia Mud Deposit (adapted from Dias et al., 2002 a, b).

The sedimentary column of the Galicia Mud Deposit provides a potentially continuous evolutionary record of the upwelling system over the last $\sim 5000$ years (Martins et al.,
2007). The coastal upwelling regime at the W Iberian Margin is characterized by seasonal and intermittent (May to September) events driven by northerly persistent winds (Fiúza, 1984). In spring and summer, the prevalence of northerly winds over the coastal oceanic surface results in an offshore displacement of water from the Coriolis effect, which forces deeper waters to upwell (Wooster et al., 1976). During upwelling events, the Eastern North Atlantic Central Water upwells under the influence of northerly Portuguese trade winds and forms a cold and nutrient-rich water band along the western coast (Fiúza, 1984; Fiúza et al., 1998). The colder waters and nutrient input from the seasonal upwelling (Prego et al., 1999) induce high productivity in this area (Fraga, 1981; Prego and Bao, 1997). Conversely, during the winter rainy season, higher amounts of sediment are introduced in the marine system because of flooding rivers (Dias et al., 2002a). Winter southwesterly storms (usually from October to April) coinciding with a downwelling regime and the development of the poleward flowing current, the Iberian Poleward Current (Peliz et al., 2003), result in the hydrodynamic transfer of resuspended material northward (Jouanneau et al., 2002) and offshore, through the bottom boundary layer (Dias et al., 2002a). Thus, the Galician upwelling system has an effect on shelf sedimentary processes, as evidenced by the distribution of muds in surface sediments (Rey and Diaz del Rio, 1987; Rey, 1990; López-Jamar et al., 1992).

Deviations in the pressure gradient between the Azores and Iceland result in changes in the length and intensity of the coastal upwelling and Iberian Poleward Current system (Frouin et al. 1990; Haynes et al., 1993). These deviations are recorded in the sediments of the NW Iberian Margin and have been investigated previously (Diz et al., 2002; Álvarez et al., 2005; Martins et al., 2007, 2012).

\section{Material and methods}

\subsection{Studied cores}

Piston core 7620 (415 cm long) was collected aboard the R.V. "Prof. W. Besnard" in the Brazilian shelf off Cabo Frio (Fig. 1a) at $22^{\circ} 56^{\prime} 31.2^{\prime \prime}$ S, $041^{\circ} 58^{\prime} 48.0^{\prime \prime} \mathrm{W}$ and water depth of $44 \mathrm{~m}$. This core was sub-sampled continuously in the laboratory, at $2-\mathrm{cm}$ intervals, and the sub-samples were frozen immediately for further freeze-drying.

The OMEX (Ocean Margin Exchange Project) core KSGX40 (164 cm long) was collected during the oceanographic cruise aboard the N.O. Côtes de la Manche, Mission GAMINEX (8/07/1998 - 19/07/1998), in the 
Galicia Mud Deposit off Ría de Vigo, at $42^{\circ} 14^{\prime} 98^{\prime} \mathrm{N}$, $09^{\circ} 01^{\prime} 01^{\prime \prime} \mathrm{W}$ and $115 \mathrm{~m}$ water depth (Fig. 1b). Sub-samples were taken at $1 \mathrm{~cm}$ intervals.

Part of the previously published data from both cores was reanalyzed in this work. The grain size data of core 7620 were studied by Nagai et al. (2009) and Gyllencreutz et al. (2010). The first authors also analyzed the abundance and diversity of benthic foraminifera and the assemblage composition, and determined the benthic foraminifera high productivity (BFHP) proxy values (according to Martins et al., 2005, 2006, 2007) along core 7620.

The grain size, the abundance and diversity of benthic foraminifera and the assemblage composition along core KSGX40 were analyzed by Martins et al. (2005, 2006, 2007). These authors also determined the BFHP values and the benthic foraminifera oxygen index (BFOI), which allowed the identification of changes in organic matter supply and the degree of sediment oxygenation. The model age of this core was established by Martins et al. (2005).

\subsection{Radiocarbon dating}

Because of the lack of suitable carbonate materials (e.g., foraminifers and mollusks), for core 7620, approximately 7 grams of total sediment at each $50 \mathrm{~cm}$ interval was separated for Accelerator Mass Spectrometry radiocarbon dating at Beta Analytic Inc. (Miami, USA). Calibrated ages were calculated using the Calib software, version $5.0 .2 \mathrm{html}$ (available at http://calib.qub.ac.uk/calib/), with the standard marine correction of 408 years and a regional reservoir effect of $\Delta \mathrm{R}=82.0 \pm 46$ years, which corresponds to the average value of three samples reported by Angulo et al. (2005) and the Marine04 calibration dataset (Hughen et al., 2004).

For core KSGX40, three radiocarbon dates from mixed foraminifera tests $(10 \mathrm{mg}$ to $20 \mathrm{mg}$ of tests with dimension $>125 \mu \mathrm{m})$ taken in selected layers $(39-40 \mathrm{~cm}, 69-70 \mathrm{~cm}$ and 134-135 cm) were analyzed using Accelerator Mass Spectrometry, at Beta Analytic Inc. (Miami, USA). Calibrated ages were calculated using the Calib software. In the model age of this core, two sigma calibration intervals were used with a standard marine reservoir correction of approximately 400 years estimated for the Iberian Margin (Soares, 1989).

\subsection{Grain size and geochemical analysis}

For both cores, grain size analysis was performed using a Malvern Mastersizer 2000 on decarbonated samples, and the calcium carbonate content was determined by weight difference prior to and after acidification of a $1 \mathrm{~g}$ sample with a $10 \%$ hydrochloric acid solution.

Elemental analysis (Al, Ca, Cr, Fe, Mg, Mn, Ti and V) of core 7620 was evaluated in the total sediment using an ICPOES technique described by Mahiques et al. (2009). Measurement precision for all elements was greater than 5\%. Method accuracy was obtained by analyzing certified sediment (HR1) and confirmed by joint proficiency analyses promoted by the National Environmental Laboratory Accreditation Programme (NELAP).

The same element concentrations ( $\mathrm{Al}, \mathrm{Ca}, \mathrm{Cr}, \mathrm{Fe}, \mathrm{Mg}$, $\mathrm{Mn}, \mathrm{Ti}$ and $\mathrm{V}$ ) were analyzed in the fine sediment fraction $(<63 \mu \mathrm{m})$ of each sample taken at $2 \mathrm{~cm}$ intervals in core KSGX40. Analyses were performed by ICP-MS (inductively coupled plasma mass spectrometry) after total digestion of the sediment with four acids $\left(\mathrm{HClO}_{4}, \mathrm{HNO}_{3}, \mathrm{HCl}\right.$ and $\left.\mathrm{HF}\right)$, at ACME Analytical Laboratories (Canada).

\subsection{Benthic foraminifera analysis}

The benthic foraminifera study samples were carefully washed through a $63-\mu \mathrm{m}$ sieve and dried in an oven at approximately $60^{\circ} \mathrm{C}$. For the benthic foraminifera assemblage study, more than 300 individuals were identified and quantified in each sample using a light microscope. Benthic foraminifera diversity was evaluated using the Shannon Index: $\mathrm{H}=-\sum$ pi.ln pi, where pi is the proportion of each species (Shannon, 1948). Foraminifera abundance (number per gram) in the core KSGX40 was determined by counting tests from a weighted sediment split, and that in core 7620 was determined by counting tests from a known volume (10 cc of sediment). Foraminifer's abundance was used to identify changes in the assemblage's standing crop in each core.

\subsection{Benthic foraminiferal proxies}

Considering that benthic foraminifera are sensitive to changes in organic carbon flux and sediment oxygenation, which is related to variations in biological productivity and near-bottom current velocity, the Benthic Foraminifera High Productivity (BFHP) index corresponding to the total percentage of species related to a high and sustainable flux of metabolizable organic matter was determined in both cores (based on Martins et al., 2005, 2006, 2007). In the core KSGX40, the BFOI was calculated to detect alterations in 
the oxygen content of sediment pore waters (based on Martins et al., 2005, 2007). The BFHP values were used to identify relative changes in the supply of organic matter to the sea floor along each core. This index was used since the amount of organic matter preserved in the sedimentary record does not represent all the flux of organic matter supplied to the sea floor in the past, since, depending on the conditions, it can be used by the biota, degraded or removed afterwards to be transported and deposited in other places.

\subsection{Statistical analysis}

The data sets were studied using a combination of univariate statistical methods, such as the moving mean average value and the mean and $\mathrm{R}$-squared values of the trend lines (with $R^{2} \geq 0.50$ or close to 0.50 ), and multivariate statistical methods. Three-point moving average values and trend lines, computed in MS Excel, were used to identify general trends in the data evolution.

To create an integrated approach towards the variability found along the cores, biotic and abiotic data were organized into a matrix and standardized using $\log (\mathrm{x}+1)$, where $\mathrm{x}$ represents the value of each variable before being submitted to a principal component analysis (PCA). The PCA was conducted using the STATISTICA (v.7.0) software package, and $p=0.05$ was used to identify significant correlations.

\section{Results and data analysis}

\subsection{Age models}

Table 1 presents the results of the radiocarbon dating. The age-depth relationship in core 7620 was established by Nagai et al. (2009) using a mixed-effect model regression that was calculated using the Cagedepth and Cage new functions, as described by Heegard et al. (2005) and available at http://www.uib.no/bot/qeprg/Age-depth.htm. Core 7620 covers an age range of $9370 \mathrm{yr}$ cal BP (Fig. 2), with sedimentation rates varying from 1.6 to $41 \mathrm{~cm} \mathrm{ka-1}$ (Table 1). The age model of core KSGX 40 records the past $\sim 4800$ yr cal BP and shows sedimentation rates varying from 25 to $41 \mathrm{~cm} \mathrm{ka}-1$ (Table 1).

\subsection{Sediment grain size and carbonate content}

Core 7620 is composed primarily of mud, with the mud fraction $(<63 \mu \mathrm{m}$ ) varying from $72 \%$ to $87 \%$ (average $78 \%$ ) and sediment mean size varying from 8.5 to $17.2 \mu \mathrm{m}$ (average $12.7 \mu \mathrm{m}$; Fig. 3a). Particles with dimension $<30 \mu \mathrm{m}$ dominate the sediment composition (varying from $54 \%$ to $72 \%$; average: $59 \%$; Fig. 3a). In core sections $120-210 \mathrm{~cm}$ and $300-$ $415 \mathrm{~cm}$, the $<30 \mu \mathrm{m}$ sediment fraction increases significantly. The carbonate content in this core varies from $23 \%$ to $28 \%$ (average $31 \%$; Fig. $3 \mathrm{a}$ ) and is supplied mostly by biogenic sources. There is a general trend of coarsening upward that is also accompanied by an increase in $\mathrm{CaCO}_{3}$. A main break in the sedimentological characteristics is observed at the $370 \mathrm{~cm}$ level $(\sim 7000 \mathrm{yr}$ cal BP), which is marked by an increase in $\mathrm{CaCO}_{3}$ content and sediment grain size (Fig. 3a).

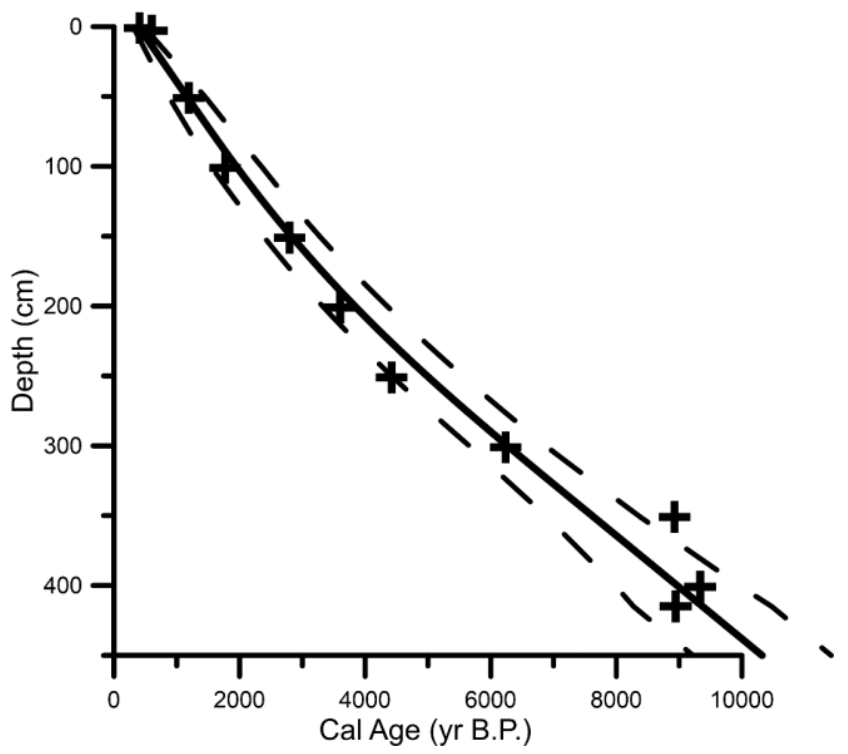

Fig. 2. Age-depth model for core 7620, based on 11 AMS radiocarbon datings. Interpolation was based on the mixed effect regression, as described by Heegard et al. (2005).

Core KSGX40 is composed primarily of sand in its lower part (164-112 cm) and by silt plus clay (50-98\%) in its upper part $(110-0 \mathrm{~cm})$. The core contains a fining upward sequence with a sedimentary mean grain size varying between 6.5 and $56.0 \mu \mathrm{m}$ (Fig. 3b). The medium to coarse sand fraction $(>500$ $\mu \mathrm{m}$ ) is only present in the lower part of the core (at 164-110 $\mathrm{cm})$ and becomes vestigial in the upper core part. The percentage of fines $(<63 \mu \mathrm{m})$ increases significantly from 80 $50 \mathrm{~cm}$ and $20-0 \mathrm{~cm}$ (Fig. 3b). The sediment fraction $<15 \mu \mathrm{m}$ is the most abundant in the total fine fractions $(<63 \mu \mathrm{m})$ of this core and presents the same general pattern of the total fine fractions. 
Tab. 1. Conventional and calibrated radiocarbon data of the cores. See text for calibration procedures. SAR - Average sediment accumulation rate.

\begin{tabular}{|c|c|c|c|c|c|}
\hline \multicolumn{6}{|c|}{ Core 7620} \\
\hline Depth $(\mathrm{cm})$ & $\begin{array}{c}\text { Beta } \\
\text { Number }\end{array}$ & $\begin{array}{c}{ }^{14} \mathrm{C} \text { age } \\
\pm 1 \sigma \mathrm{Cal} \mathrm{BP}\end{array}$ & $\delta^{13} \mathrm{C}$ & $\begin{array}{c}{ }^{14} \mathrm{C} \text { age } \\
\pm 2 \sigma \mathrm{Cal} \mathrm{BP} \\
\end{array}$ & $\begin{array}{c}\text { SAR } \\
\mathbf{k a}^{-1}\end{array}$ \\
\hline $0-2$ & 217363 & $850 \pm 40$ & -21.7 & $850 \pm 40$ & 5.1 \\
\hline $2-4$ & 217364 & $1120 \pm 40$ & -21.4 & $1120 \pm 40$ & 3.3 \\
\hline $50-52$ & 217365 & $1710 \pm 50$ & -21.5 & $1710 \pm 50$ & 41.0 \\
\hline $100-102$ & 217366 & $2260 \pm 50$ & -21.3 & $2260 \pm 50$ & 28.3 \\
\hline $150-152$ & 217367 & $3120 \pm 40$ & -21.5 & $3120 \pm 40$ & 17.7 \\
\hline $200-202$ & 217368 & $3780 \pm 40$ & -21.5 & $3780 \pm 40$ & 9.8 \\
\hline $250-252$ & 217369 & $4380 \pm 40$ & -21.4 & $4380 \pm 40$ & 22.7 \\
\hline $300-302$ & 217370 & $5910 \pm 40$ & -21.5 & $5910 \pm 40$ & 8.0 \\
\hline $350-352$ & 217371 & $8440 \pm 40$ & -21.9 & $8440 \pm 40$ & 5.6 \\
\hline $400-402$ & 217372 & $8740 \pm 60$ & -22.2 & $8740 \pm 60$ & 5.4 \\
\hline $414-416$ & 271373 & $8450 \pm 50$ & -22.8 & $8450 \pm 50$ & 1.6 \\
\hline \multicolumn{6}{|c|}{ Core KSGX 40} \\
\hline Depth $(\mathrm{cm})$ & $\begin{array}{c}\text { Beta } \\
\text { Number }\end{array}$ & $\begin{array}{c}{ }^{14} \mathrm{C} \text { age } \\
\pm 1 \sigma \mathrm{Cal} \mathrm{BP} \\
\end{array}$ & $\begin{array}{c}13 \mathrm{C} / 12 \mathrm{C} \\
\text { Ratio (\%o) }\end{array}$ & $\begin{array}{c}{ }^{14} \mathrm{C} \text { age } \\
\pm 2 \sigma \mathrm{Cal} \mathrm{BP} \\
\end{array}$ & $\begin{array}{c}\text { SAR } \\
\left(\mathrm{cm} \mathrm{ka}^{-1}\right)\end{array}$ \\
\hline $39-40$ & 154383 & 1080-990 & -1.2 & $1140-950$ & 27 \\
\hline $69-70$ & 154384 & $2360-2320$ & 0.0 & $2460-2300$ & 25 \\
\hline $134-135$ & 154385 & $4410-4300$ & 1.1 & $4440-4240$ & 41 \\
\hline
\end{tabular}

\subsection{Geochemical composition}

The maximum, minimum, mean and standard deviation of element concentrations and carbonate content for both cores are presented in Table 2. Concentrations of $\mathrm{Ca}, \mathrm{Fe}$ and $\mathrm{Mg}$, as well as carbonate content are higher in core 7620 than in core KSGX40, which has higher concentrations of $\mathrm{Al}$, $\mathrm{Mn}, \mathrm{Ti}$ and $\mathrm{V}$. In both cores, the concentrations of $\mathrm{Cr}$ are similar.

Core 7620 shows a decreasing trend of $\mathrm{Al}$ from the base to the top of the core and lower concentrations of $\mathrm{Ca}$ in the upper part (Fig. 4a), whereas core KSGX40 shows an increasing trend for $\mathrm{Al}$ and a decreasing one for $\mathrm{Ca}$ content (Fig. 4b). The Fe/Ca and Ti/Ca ratios were used to identify variations in terrigenous input (Arz et al., 1998), and the $\mathrm{Ca} / \mathrm{Al}$ ratio, to provide indirect information about biogenic/terrigenous input (Haslett et al., 2006; Bernárdez et al. 2008; Sun et al., 2008). Changes in these ratios indicate an alteration in the sediment composition. In core 7620 major variations occurred in the following four sections: 415-325 $\mathrm{cm}, 325-283 \mathrm{~cm}, 283-167 \mathrm{~cm}$ and $167-0 \mathrm{~cm}$ (Fig. 4a). The values of these ratios along core KSGX40 also change significantly in the following four sections: $164-85 \mathrm{~cm}, 80-50$ $\mathrm{cm}, 50-20 \mathrm{~cm}$ and $20-0 \mathrm{~cm}$ (Fig. 4b).

In order to evaluate variations in redox conditions, the element/ $\mathrm{Al}$ ratios of $\mathrm{Cr}, \mathrm{Fe}, \mathrm{Mn}$ and $\mathrm{V}$ (Morford and Emerson, 1999; Moreno et al., 2004) were used. In core 7620 , the results show the expected significant positive correlation between $\mathrm{V} / \mathrm{Al}$ and $\mathrm{Cr} / \mathrm{Al}(\mathrm{r}=0.73)$ and $\mathrm{Fe} / \mathrm{Al}$ $(\mathrm{r}=0.62)$ and $\mathrm{Mn} / \mathrm{Al}(\mathrm{r}=0.57)$, with the ratios rising in two main sections: $323-193 \mathrm{~cm}$ and $159-0 \mathrm{~cm}$ (Fig. 5a). 


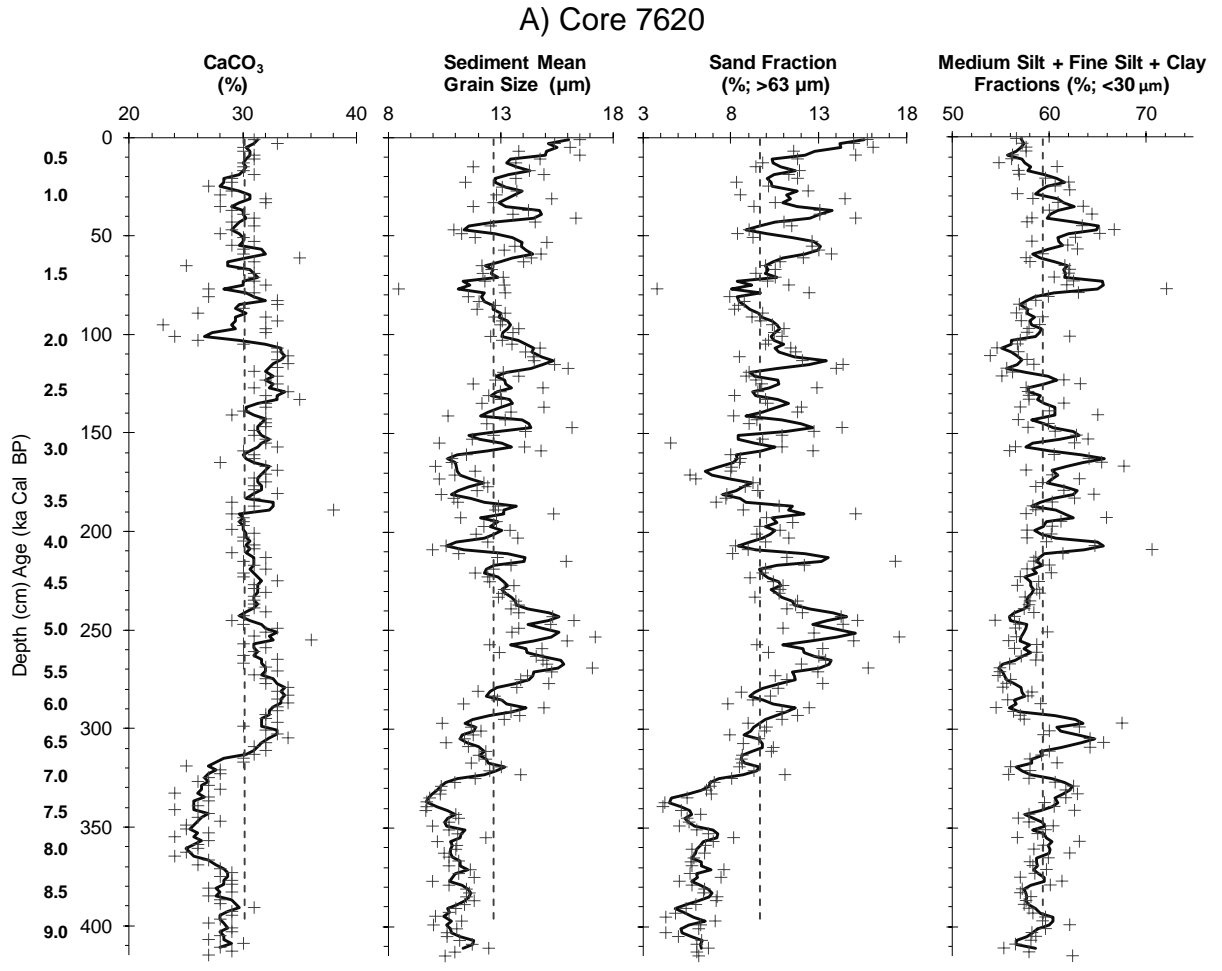

B) Core KSGX 40

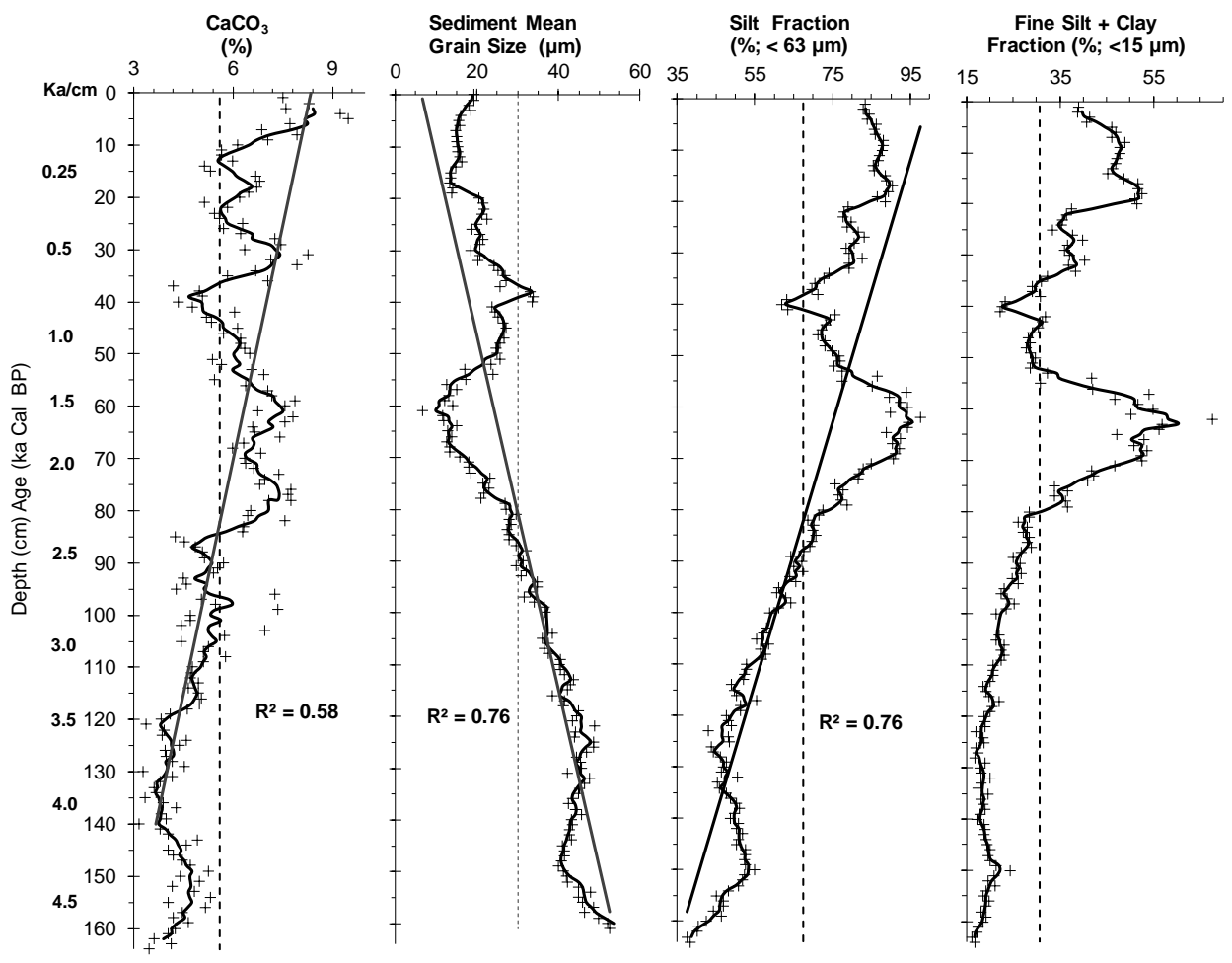

Fig. 3. Sediment grain size data and carbonate content along cores: A) 7620 and B) KXGX 40. 


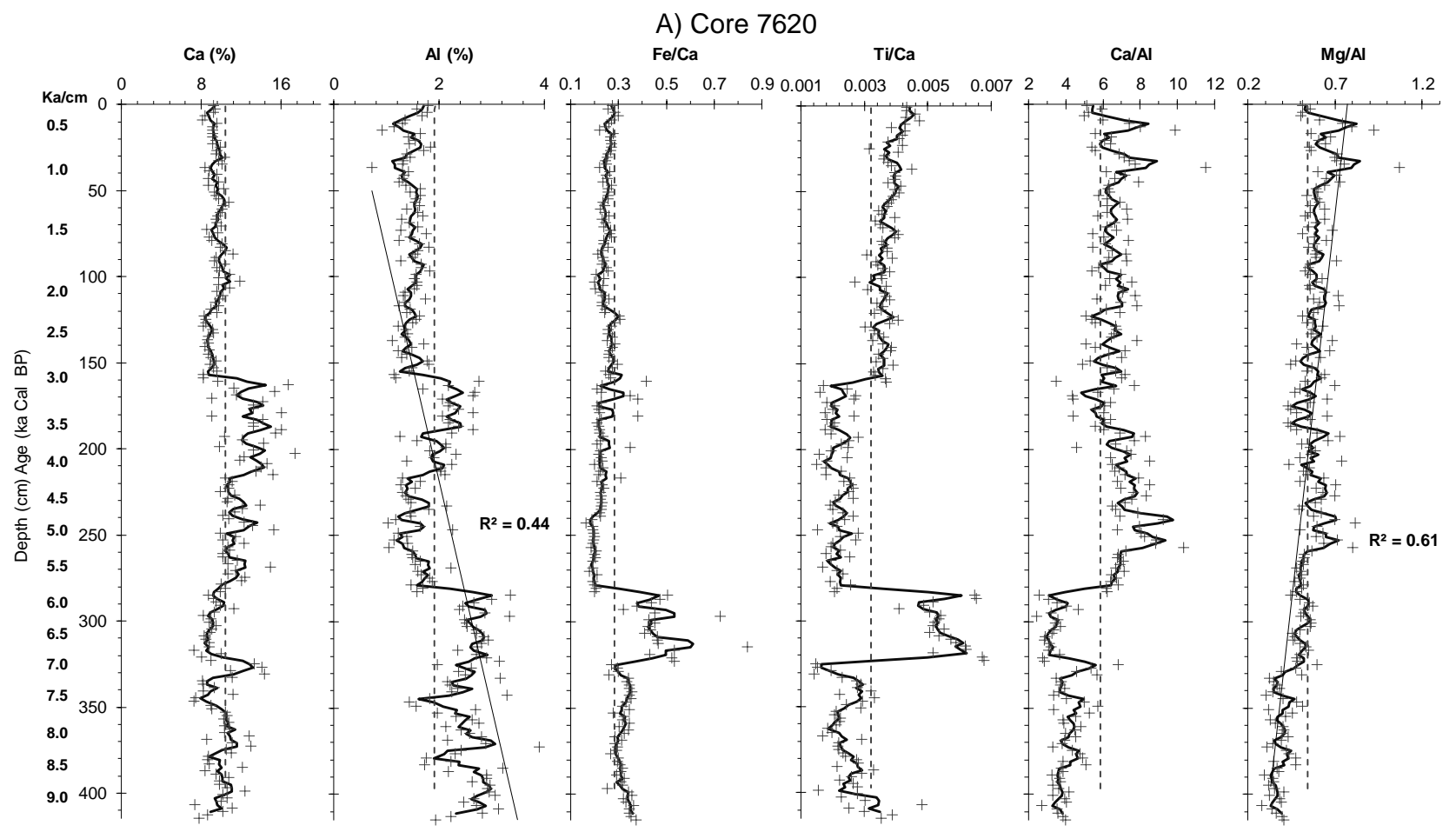

B) Core KSGX 40
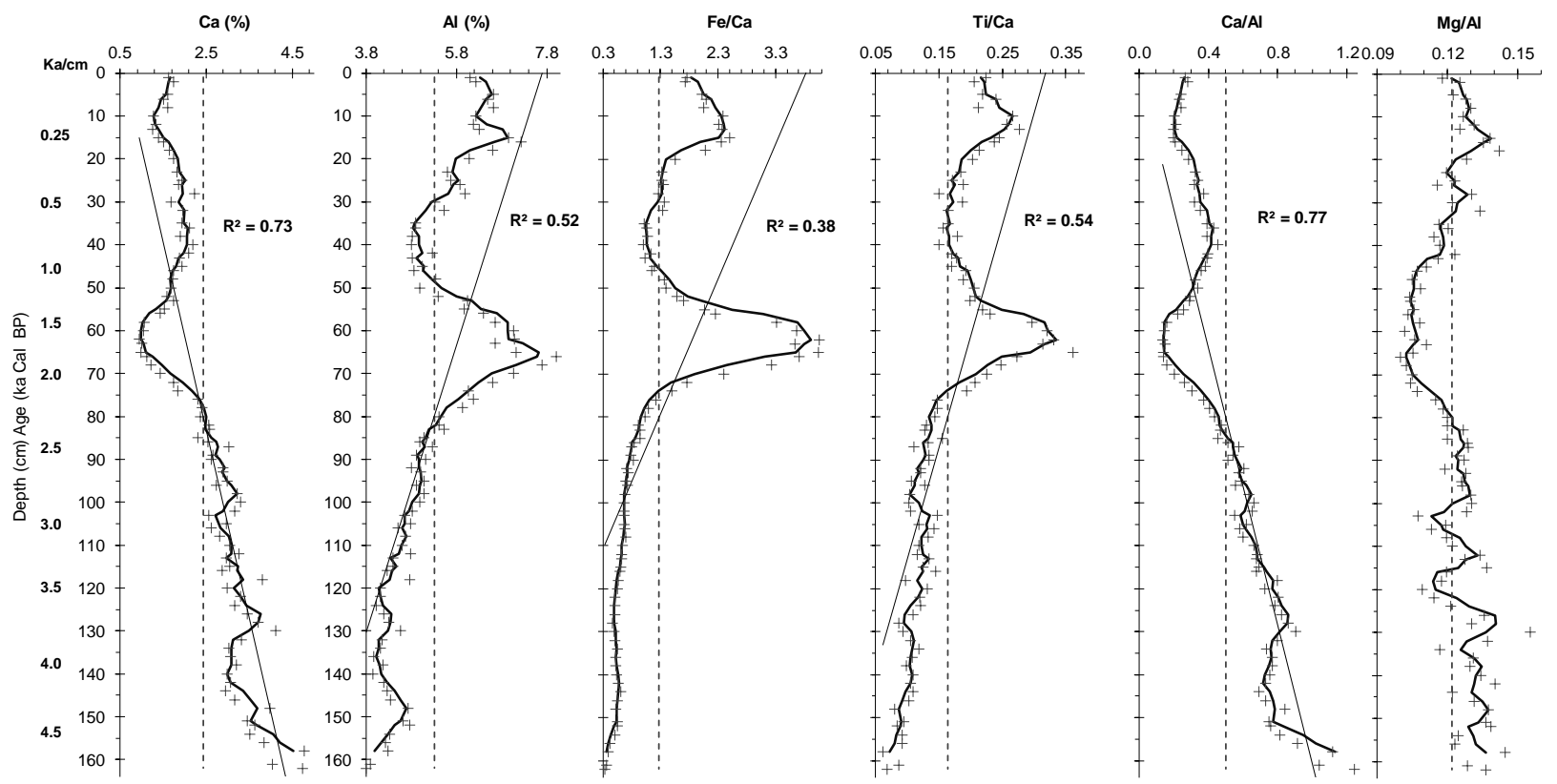

Fig. 4. Depth plot of results of $\mathrm{Ca}$ and $\mathrm{Al}$ concentrations and $\mathrm{Fe} / \mathrm{Ca}, \mathrm{Ti} / \mathrm{Ca}, \mathrm{Ca} / \mathrm{Al}$ and $\mathrm{Mg} / \mathrm{Al}$. Core chronology, data (points), and the data mean value and mean moving averages based on three results (grey line) are represented in each depth plot. The regression line with $\mathrm{R}^{2}$ value is also presented for all variables except $\mathrm{Mg} / \mathrm{Al}$. 
Tab. 2. Maximum, minimum, median and standard deviation of the element concentrations and carbonate content.

\begin{tabular}{|c|c|c|c|c|c|c|c|c|c|}
\hline \multirow{2}{*}{$\begin{array}{c}\text { Chemical } \\
\text { Elements }\end{array}$} & \multicolumn{4}{|c|}{ Core $\mathbf{7 6 2 0}$} & \multicolumn{4}{c|}{ Core KSGX40 } \\
\cline { 2 - 10 } & Max. & Min & Med & St.Dev. & Max. & Min & Med & St.Dev. \\
\hline $\mathbf{A l}$ & $\%$ & 3.90 & 0.73 & 1.92 & 0.60 & $\mathbf{8 . 0 1}$ & 3.81 & 5.30 & $\mathbf{1 . 7 5}$ \\
\hline $\mathbf{C a}$ & $\%$ & $\mathbf{1 7 . 4 3}$ & 7.26 & 10.39 & $\mathbf{1 . 9 1}$ & 4.77 & 0.95 & 2.44 & 1.58 \\
\hline $\mathbf{C r}$ & $\mathrm{mg.kg^{-1 }}$ & 80 & 27 & 40 & 9 & 71 & 23 & 38 & $\mathbf{2 0}$ \\
\hline $\mathbf{F e}$ & $\%$ & $\mathbf{7 . 4 0}$ & 1.85 & 2.87 & 0.74 & 4.19 & 1.44 & 2.40 & 1.15 \\
\hline $\mathbf{M g}$ & $\%$ & $\mathbf{1 . 7 0}$ & 0.69 & 0.99 & 0.20 & 0.98 & 0.45 & 0.64 & 0.22 \\
\hline $\mathbf{M n}$ & $\mathrm{mg} \cdot \mathrm{kg}^{-1}$ & 242 & 98 & 135 & 33 & $\mathbf{2 9 0}$ & 185 & 218 & 44 \\
\hline $\mathbf{T i}$ & $\%$ & 0.06 & 0.02 & 0.03 & 0.01 & $\mathbf{0 . 4 2}$ & 0.29 & 0.34 & 0.05 \\
\hline $\mathbf{V}$ & $\mathrm{mg} \cdot \mathrm{kg}^{-1}$ & $\mathbf{7 7}$ & 17 & 30 & 9 & $\mathbf{1 1 6}$ & 32 & 58 & $\mathbf{3 6}$ \\
\hline Carb. & $\%$ & $\mathbf{3 8}$ & 23 & 30 & 3 & 18 & 2 & 9 & 3 \\
\hline
\end{tabular}

In core KSGX40, the expected significant positive correlation between $\mathrm{V} / \mathrm{Al}$ and $\mathrm{Cr} / \mathrm{Al}(\mathrm{r}=0.67)$ and $\mathrm{Fe} / \mathrm{Al}$ $(\mathrm{r}=0.94)$ was observed, as well as a significant negative correlation with $\mathrm{Mn} / \mathrm{Al}(-0.67)$. The values of $\mathrm{Cr} / \mathrm{Al}, \mathrm{Fe} / \mathrm{Al}$ and $\mathrm{V} / \mathrm{Al}$ increase between $80-50 \mathrm{~cm}$ and $0-20 \mathrm{~cm}$, whereas the $\mathrm{Mn} / \mathrm{Al}$ values decrease in those core sections (Fig. 5b).

\subsection{Benthic foraminifera results}

\subsubsection{Core 7620}

The abundance of benthic foraminifera along core 7620 ranges from 400 to 16,600 specimens per sample (Fig. 5a). The Shannon Index varies between 1.1 and 2.7. The lowest values for foraminifer's abundance and diversity were recorded at the core base.

Shallow water species (i.e., Psedudononion atlanticum and Buliminella elegantissima) dominate the assemblages in the core base (at 9300 yr cal BP), but their percentage decreases until 6000 yr cal BP, subsequently becoming rare (Fig. 6a). The BFHP index reaches highest values in the core sections between $410-320 \mathrm{~cm}$ and in the upper section $120-0 \mathrm{~cm}$.

\subsubsection{Core KSGX40}

The depth plots of benthic foraminifer's abundance and diversity, BFHP and BFOI indices values along core KSGX40, are presented in Figure 6b. Whereas the BFOI index and foraminifer's abundance and diversity reach highest values in core section $164-76 \mathrm{~cm}$, the BFHP index mostly rises in the upper section of the core $(75-0 \mathrm{~cm})$.

\subsection{Principal Component Analysis (PCA)}

\subsubsection{PCA for core 7620}

Selected abiotic and biotic data were used for principal component analysis (PCA) of both cores. Figure 7 presents the biplot of variables of the first three factors of the PCA, which correspond to $62 \%$ of the total explained variance of the data in core 7620. The biplot of Factor 1 against Factor 2 differentiates four groups of variables (explained variance $50 \%)$. Group I is composed of fines $(<63 \mu \mathrm{m}), \mathrm{Al}, \mathrm{Fe} / \mathrm{Ca}$ (terrigenous proxy) and foraminifera shallow-water species. Group II, which is negatively correlated with group I, is composed of sediment mean grain size, carbonate content, $\mathrm{Ca} / \mathrm{Al}, \mathrm{Mn} / \mathrm{Al}, \mathrm{Mg} / \mathrm{Al}, \mathrm{Cr} / \mathrm{Al}, \mathrm{Fe} / \mathrm{Al}$ and $\mathrm{V} / \mathrm{Al}$. In this group, carbonate content and $\mathrm{Ca} / \mathrm{Al}$ represent the biogenic contribution for the sediment composition. The values of $\mathrm{Cr} / \mathrm{Al}, \mathrm{V} / \mathrm{Al}, \mathrm{Mn} / \mathrm{Al}$ and $\mathrm{Fe} / \mathrm{Al}$ can be used as redox sensitive proxies, and $\mathrm{Mg} / \mathrm{Al}$ as a terrigenous proxy. Group III contains $\mathrm{Ca}$ and $\mathrm{Ca} / \mathrm{Al}$, and is in opposition to group $\mathrm{IV}$, which only comprises $\mathrm{Ti} / \mathrm{Ca}$ and $\mathrm{Fe} / \mathrm{Ca}$ (terrigenous proxies).

The biplot of Factor 1 against Factor 3 differentiates two new groups of variables (explained variance 13\%): groups $\mathrm{V}$ and VI. Group V encompasses Shannon Index values and foraminifera-specific richness. These variables are opposed to BFHP (group VI). 
A) Core 7620

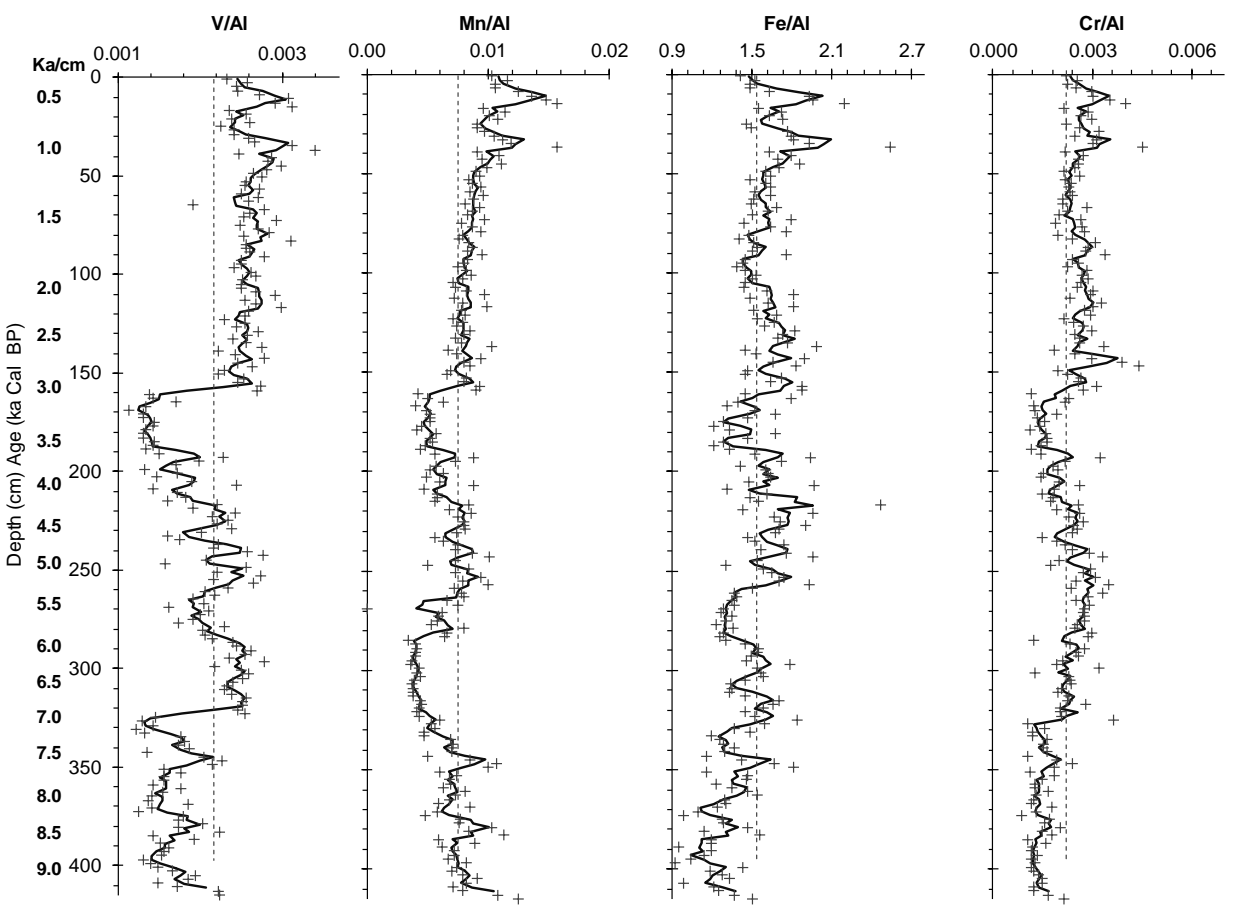

B) Core KSGX 40

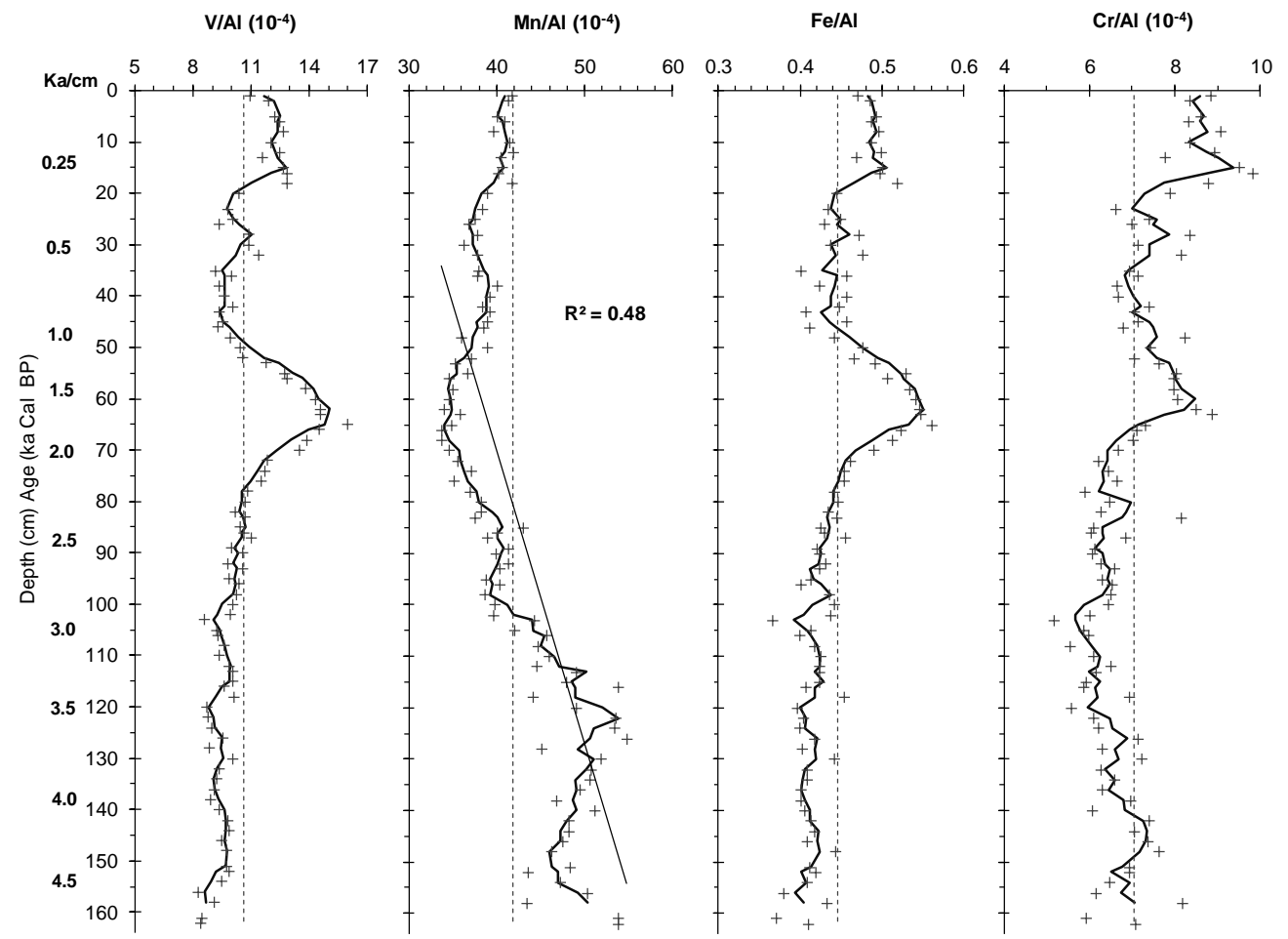

Fig. 5. Depth plot of results of V/Al, Mn/Al, Fe/Al and Cr/Al for cores 7620 and KSGX 40. Core chronology, data (points), the data mean value and mean moving averages based on three results (grey line) are represented in each depth plot. The regression line with $\mathrm{R}^{2}$ value is also presented for $\mathrm{Mn} / \mathrm{Al}$ of core KSGX 40. 
A) Core 7620

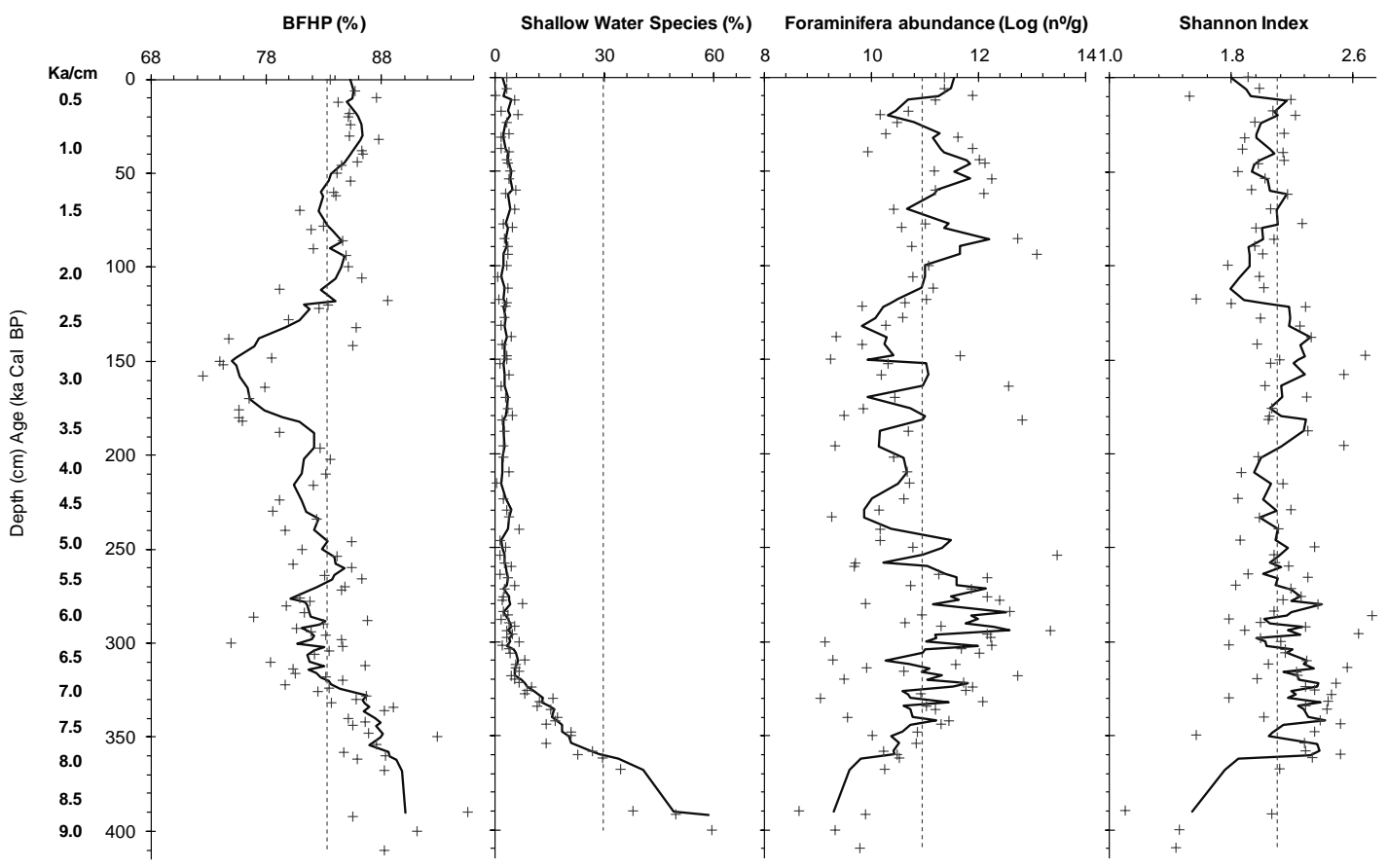

B) Core KSGX40

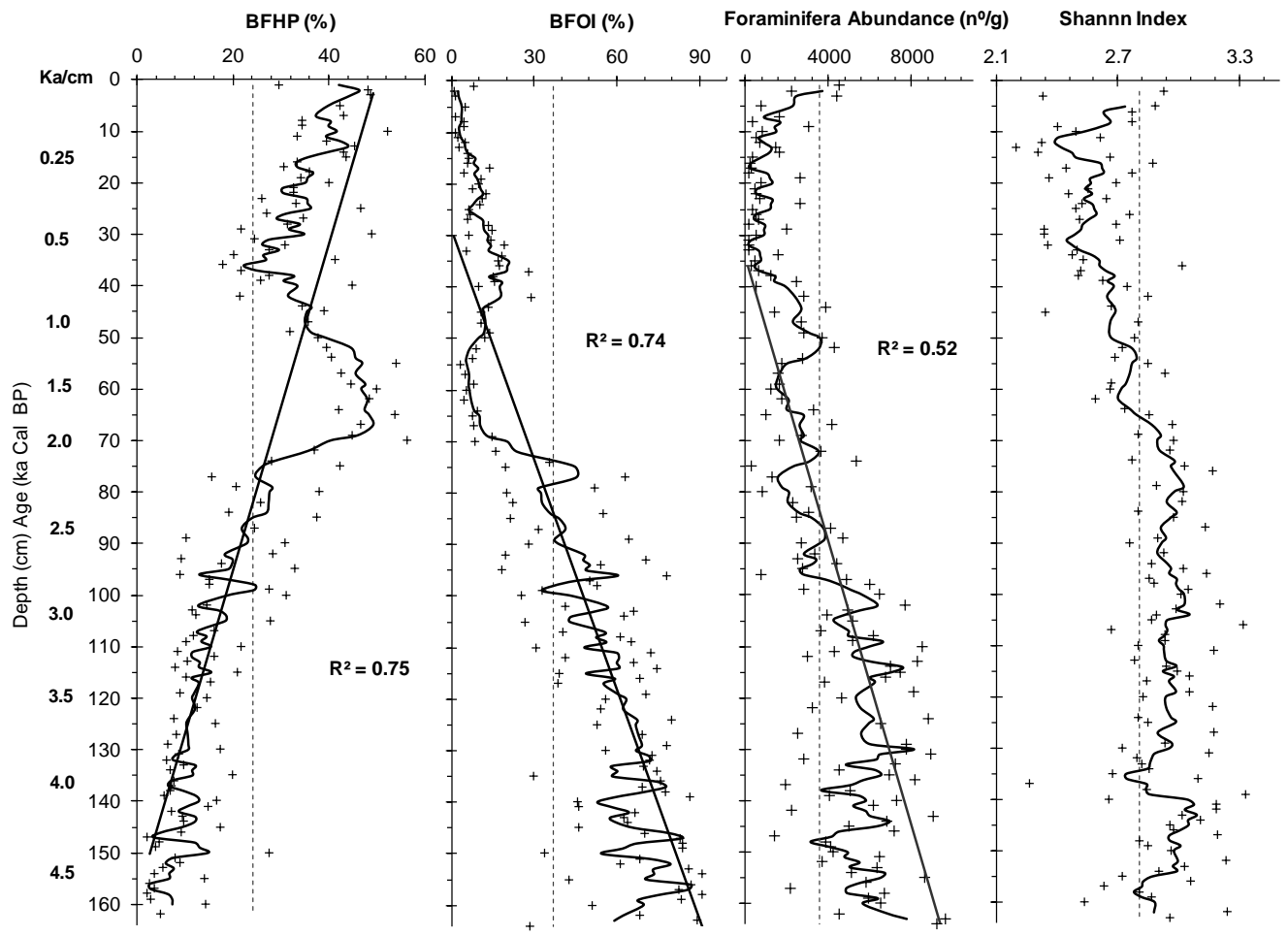

Fig. 6. Depth plot of results of BFHP, foraminifera abundance, and Shannon Index, for both cores. Percentage of species more common in costal shallow waters is also shown for core 7620, as well as BFOI values for core KSGX40. Core chronology, data (points), and the data mean value and mean moving averages based on three results (grey line) are represented in each depth plot. The regression line with $\mathrm{R}^{2}$ value is also presented, where the $\mathrm{R}^{2}$ value is significant. 


\subsubsection{PCA Core KSGX40}

Figure 8 presents the biplot of variables of the two first factors of the PCA, which corresponds to $82 \%$ of the total variance of the data in core KSGX40. The biplot of Factor 1 against Factor 2 differentiates four groups of variables. Factor 1 establishes Group 1, which is composed of the fine fraction $(<63 \mu \mathrm{m})$ and the fine silt plus clay fraction $(<15$ $\mu \mathrm{m}) ; \mathrm{Cr} / \mathrm{Al}, \mathrm{Fe} / \mathrm{Al}$ and $\mathrm{V} / \mathrm{Al}$ (redox conditions proxies); $\mathrm{Al}$ concentrations and $\mathrm{Fe} / \mathrm{Ca}$ and $\mathrm{Ti} / \mathrm{Ca}$ (terrigenous proxy), and BFHP (productivity proxies). This group is negatively correlated with Group 2, which includes $\mathrm{Ca}, \mathrm{Ca} / \mathrm{Al}$, and carbonates (related mostly to biogenic sources). It is also negatively correlated with $\mathrm{Ti} / \mathrm{Al}$ (terrigenous proxy), $\mathrm{Mn} / \mathrm{Al}$ (redox proxy) and BFOI (sediment oxygenation proxy) and sediment mean grain size (hydrodynamics proxy).

\subsubsection{Factor Score values of PCA for core 7620}

Based on these results, the plots against time of Factor Scores 1, 2 and 3 for core 7620 are presented in Figure 9a. In this core, Factor Score 1 variations may be used as indicators of changes in the hydrodynamics of bottom currents and their role in the transport of sediment, as suggested by the positive correlation with the $\mathrm{Al}(0.87)$, $\mathrm{Fe} / \mathrm{Ca}(0.51)$ and the fine fraction (0.58), and the negative correlation with SMGS (-0.72) and $\mathrm{Mg} / \mathrm{Al}(-0.89)$. Factor Score 2 is considered an indicator of changes in the biogenic/terrigenous contribution, as suggested by a significant and positive correlation with $\mathrm{Ca}(0.65)$ and $\mathrm{Ca} / \mathrm{Al}$ (0.53), and a negative correlation with $\mathrm{Fe} / \mathrm{Ca}(-0.78)$ and $\mathrm{Ti} / \mathrm{Ca}(-0.87)$. Factor Score 3 can be seen as an indicator of changes in benthic foraminifera assemblage structure indicated by the positive correlation with the Shannon Index $(0.75)$ and specific richness (0.74) and negative with the BFHP (-0.62).

\subsubsection{Factor Score values of PCA for core KSGX40}

Figure $9 \mathrm{~b}$ presents the plots against time of Factor Scores 1 and 2 for core KSGX40. Factor Score 1 variations are used as an indicator of changes in the hydrodynamics of bottom currents and their role in sediment transport and deposition, as suggested by a significant and positive correlation with the fine fraction (0.97) and sediment fraction $<15 \mu \mathrm{m}(0.97)$. This factor score also has significant positive correlations (varying between 0.84 and 0.97 ) with other variables such as
$\mathrm{Al}, \mathrm{Fe} / \mathrm{Ca}, \mathrm{Fe} / \mathrm{Al}, \mathrm{Ti} / \mathrm{Ca}, \mathrm{Cr} / \mathrm{Al}, \mathrm{V} / \mathrm{Al}$ and BFHP. It also has significant negative correlations (varying between 0.83 and 0.95 ) with carbonate content, $\mathrm{Ca}, \mathrm{Ca} / \mathrm{Al}, \mathrm{Ti} / \mathrm{Al}, \mathrm{Mn} / \mathrm{Al}$ and BFOI.

\section{Discussion}

\subsection{Changes in bottom bydrodynamic conditions}

\subsubsection{Cabo Frio region}

The plot against time for PCA Factor Score 1 (Fig. 9a) suggests that the area of Cabo Frio, where core 7620 was collected, was submitted to lower hydrodynamic conditions between 9370-7000 $\mathrm{yr}$ cal BP and an increasing trend in hydrodynamism afterwards. During this period, benthic foraminifera assemblages are dominated by shallow water species (i.e., $P$. atlanticum and B. elegantissima) that are also considered to be indicative of the input of continental organic matter in the SE Brazilian shelf (Burone et al., 2006). Taking into account the nearby presence of the Paraíba do Sul River, it seems reasonable to assume that the fine sediments found during this period are likely a result of a relatively more effective contribution of this river to the Cabo Frio region as a result of lower sea-level conditions. The present current depth at which core 7620 was taken is $44 \mathrm{~m}$. In the period between 9370-7000 $\mathrm{yr}$ cal BP it would be lower than that, probably about $35 \mathrm{~m}$. Thus, the sediments of this core are dominated by fine-sized particles deposited when the water depth was possibly as much as 40 $\mathrm{m}$ ( $35 \mathrm{~m}$ for the core top, plus $4 \mathrm{~m}$ considering the core length) and this location may have been in the outer surf zone. It was under the influence of low bottom hydrodynamic conditions.

After sea-level stabilization, relatively high energetic conditions were observed between $\sim 6000-4000$ yr cal BP and since $3000 \mathrm{yr}$ cal BP. The first period most likely reflects a position of the Brazil Current closer to the shelf, during higher sea-level conditions (Mahiques et al., 2007), as this period spans the Holocene transgression. The second period, the last $3000 \mathrm{yr}$ cal BP, marks the onset of the modern oceanographic setting in the Cabo Frio area.

\subsubsection{Galician region}

The plot against time of the PCA Factor Score 1 for core KSGX40 (Fig. 9b) shows that the Galician area at the outer continental shelf was subjected to stronger hydrodynamism at $\sim 4800 \mathrm{yr}$ cal BP and progressively weaker hydrodynamic conditions afterwards until the present day. From 4800-2500 
yr cal BP, the coarser sediments rich in detrital minerals and carbonate particles indicate the prevalence of high nearbottom current velocities (Martins et al., 2007). The hydrodynamic conditions in this area became weaker from $\sim 2200-1200 \mathrm{yr} \mathrm{cal} \mathrm{BP}$ and since $\sim 500 \mathrm{yr} \mathrm{cal} \mathrm{BP}(80-50 \mathrm{~cm}$ and $20-0 \mathrm{~cm}$ ), as suggested by the finer sedimentation (muddy sediments and finer detrital minerals) occurring during the two muddy intervals (Martins et al., 2007).

\subsection{Proxies of terrigenous input}

\subsubsection{Cabo Frio region}

In core 7620, the plot against time of the PCA Factor Score 2 (Fig. 9a) shows four phases of terrigenous input. The first phase, determined to be in the interval from 9370-7000 yr cal BP is marked in general by finer sediments (Fig. 3a), intermediate values of $\mathrm{Fe} / \mathrm{Ca}$, Ti/ $\mathrm{Ca}$ and $\mathrm{Ca} / \mathrm{Al}$ (Fig. 4a) and lower rates of sedimentation (Fig. 9a). Between $7000 \mathrm{yr}$ cal $\mathrm{BP}$ and $5800 \mathrm{yr}$ cal BP, the area received a terrigenous contribution characterized by relatively coarser particles (Fig. 3a), high values of $\mathrm{Fe} / \mathrm{Ca}$ and $\mathrm{Ti} / \mathrm{Ca}$ and low values of $\mathrm{Ca} / \mathrm{Al}$ (Fig. 4a), and slightly increasing sedimentation rates (Fig. 9a). In the period between $5800 \mathrm{yr} \mathrm{cal} \mathrm{BP}$ and $3000 \mathrm{yr}$ cal BP, sedimentation rates increased gradually (Fig. 9a), sediments became progressively finer (with a higher content of clay and silt sediment fractions, Fig. 3a), Fe/Ca and $\mathrm{Ti} / \mathrm{Ca}$ values decreased and $\mathrm{Ca} / \mathrm{Al}$ and $\mathrm{Mg} / \mathrm{Al}$ values increased (Fig. 4a). In the period from $3000 \mathrm{yr}$ cal BP until the present, the sedimentation rate augmented. The sediments became coarser (Fig. 3a) and were characterized by relatively high values of $\mathrm{Ti} / \mathrm{Al}$ and $\mathrm{Ca} / \mathrm{Al}$ (Fig. 4a). During this period, $\mathrm{Mg} / \mathrm{Al}$ values also increased (Fig. 4a).

Regarding the Cabo Frio region, based on changes in mangrove vegetation, Scheel-Ybert (2000) identified modifications in humidity during the period between 5500 and $1400 \mathrm{yr}$ cal BP. Two humid episodes (5500 to $4900 \mathrm{yr}$ cal BP and 2300 to $2000 \mathrm{yr}$ cal BP) were identified, alternating with dry phases (4900 to $2300 \mathrm{yr}$ cal BP and 2000 to $1400 \mathrm{yr}$ cal BP).

Climatic changes in the Cabo Frio region during the middle and late Holocene were also discussed by Sylvestre et al. (2005) and Laslandes et al. (2006). Based on changes in diatom assemblages in cores from a hypersaline lagoon, these authors recognized variations in humidity and correlated them with the ENSO variability (Martin et al., 1988, 1993). According to Ledru et al. (1998), the interval between $5800 \mathrm{yr}$ cal BP and the present is consistent with a trend of increasing humidity described as a consequence of changes in the wind regime and linked to the advance of polar masses. These more humid periods may have caused the increased rate of sediment accumulation recorded after $5800 \mathrm{yr}$ cal BP. However, core 7620 records a decreased rate of sediment accumulation after $2500 \mathrm{yr}$ cal BP, which may be related to an increase in aridity after $2400 \mathrm{yr}$ cal BP (Sylvestre et al., 2005; Laslandes et al., 2006).

\subsubsection{Galician region}

According to Martins et al. (2007), from 4800-2200 yr cal BP, coarser sediments composed mostly of detrital minerals, such as quartz and feldspars, were deposited in core KSGX40. This relatively coarse sequence was followed by two muddy layers characterized by higher percentages of fine detrital minerals and marked by the increase of $\mathrm{Al}$ content, $\mathrm{Fe} / \mathrm{Ca}$ and $\mathrm{Ti} / \mathrm{Ca}$ values (Fig. 4b), which suggests increased deposition of phyllosilicates such as clay minerals containing $\mathrm{Ti}$ and $\mathrm{Fe}$.

Both core sections may also be enriched by other minerals such as hematite and anatase. These minerals are common in igneous and metamorphic rocks of the Iberian Peninsula. Thus they are generally found in continental and shelf micaceous sediments, and in ilmenite, which is generally associated with gabbros and anorthosites also common in this region (Julivert et al., 1980).

During both intervals, the $\mathrm{Mg} / \mathrm{Al}$ values tended to decrease (Fig. 4 b). Magnesium may be associated, for instance, with hornblendes, which are dark amphiboles common in igneous and metamorphic rocks such as granites, syenites, diorites, gabbros, basalts, andesites, gneisses and schists, or with magnesite, which is common in metamorphic serpentine rocks also common in this region (Julivert et al., 1980). Therefore, decreasing values of $\mathrm{Mg} / \mathrm{Al}$ may indicate lower hard rock erosion associated with decreased rainfall.

\subsection{Productivity proxies and changes in sediment redox conditions}

\subsubsection{Cabo Frio region}

In core 7620, the plot against time for PCA Factor Score 3 (Fig. 9a) shows three main phases of biological productivity and organic matter input inferred from BFHP values (Fig. 6a). Relatively high productivity must have taken place between 9370 and $7000 \mathrm{yr}$ cal BP. The lowest productivity occurred between 7000 and $2500 \mathrm{yr}$ cal BP and the highest productivity occurred after 2,500 $\mathrm{yr}$ cal $\mathrm{BP}$, which is suggested by high values of BFHP. 
Core 7620

Factor Loadings, Factor 1 vs. Factor 2

Rotation: Unrotated

Extraction: Principal components

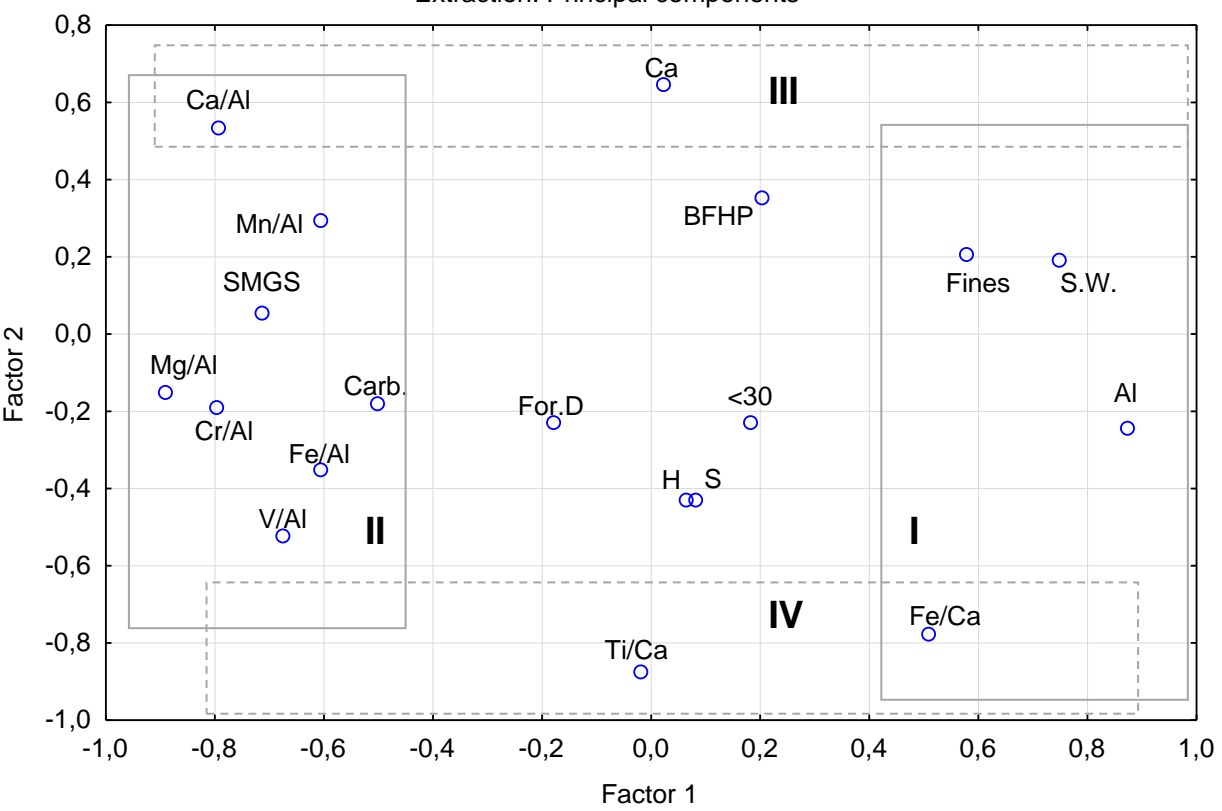

A

Factor Loadings, Factor 1 vs. Factor 3

Rotation: Unrotated

Extraction: Principal components

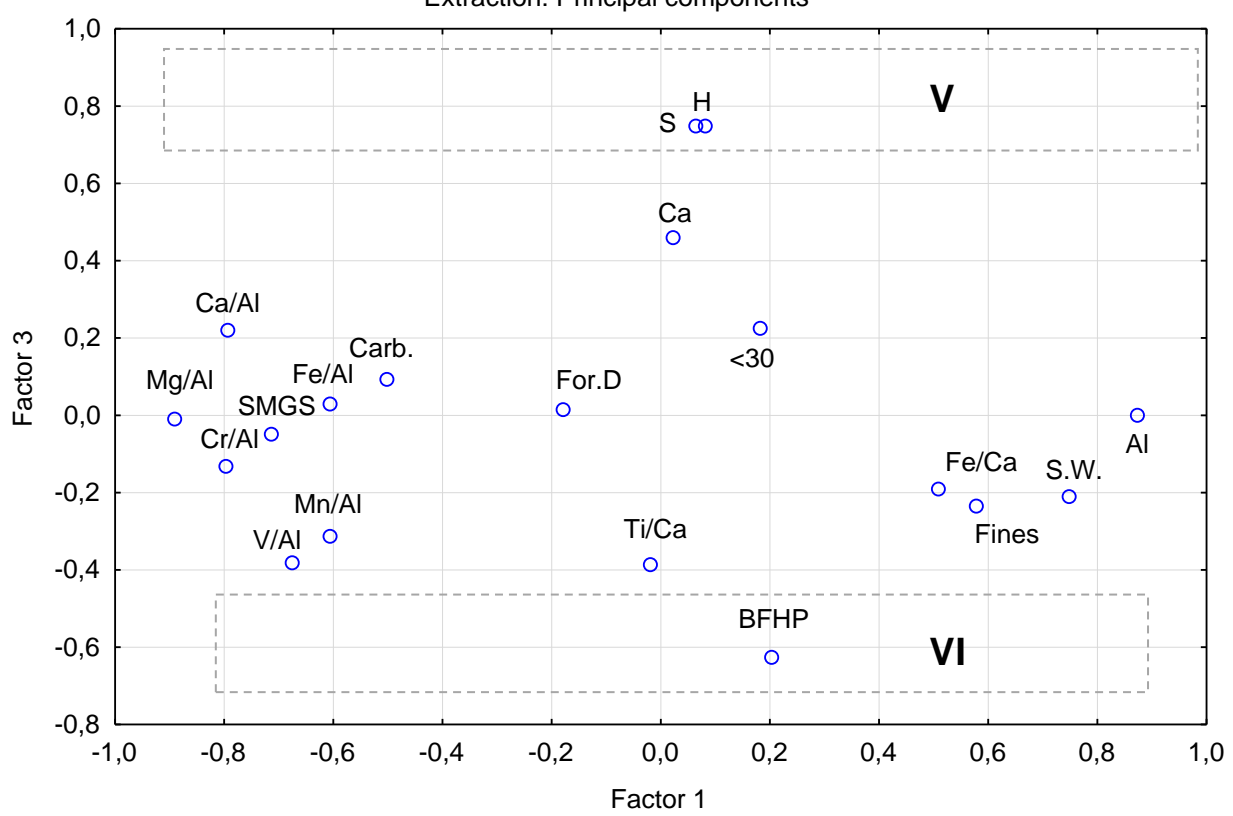

B

Fig. 7. Principal Component Analysis for core 7620, based on the following: Geochemical data (Al, Ca, Ca/Al, Cr/Al, Fe/Al, Fe/Ca, $\mathrm{Mg} / \mathrm{Al}, \mathrm{Mn} / \mathrm{Al}, \mathrm{Ti} / \mathrm{Al}, \mathrm{Ti} / \mathrm{Ca}, \mathrm{V} / \mathrm{Al}$ and Carb. - carbonates). Biological variables (BFHP - Benthic Foraminifera High Productivity proxy; S.W. - shallow water species; H - Shannon Index; S - foraminiferal specific richness; and For.D - foraminifera abundance). Grain size (SMGS - sediment mean grain size; Fines - fine fraction $<63 \mu \mathrm{m}<30 \mu \mathrm{m}$, medium silt + fine silt plus clay fractions). 
Core KSGX 40

Factor Loadings, Factor 1 vs. Factor 2

Rotation: Unrotated

Extraction: Principal components

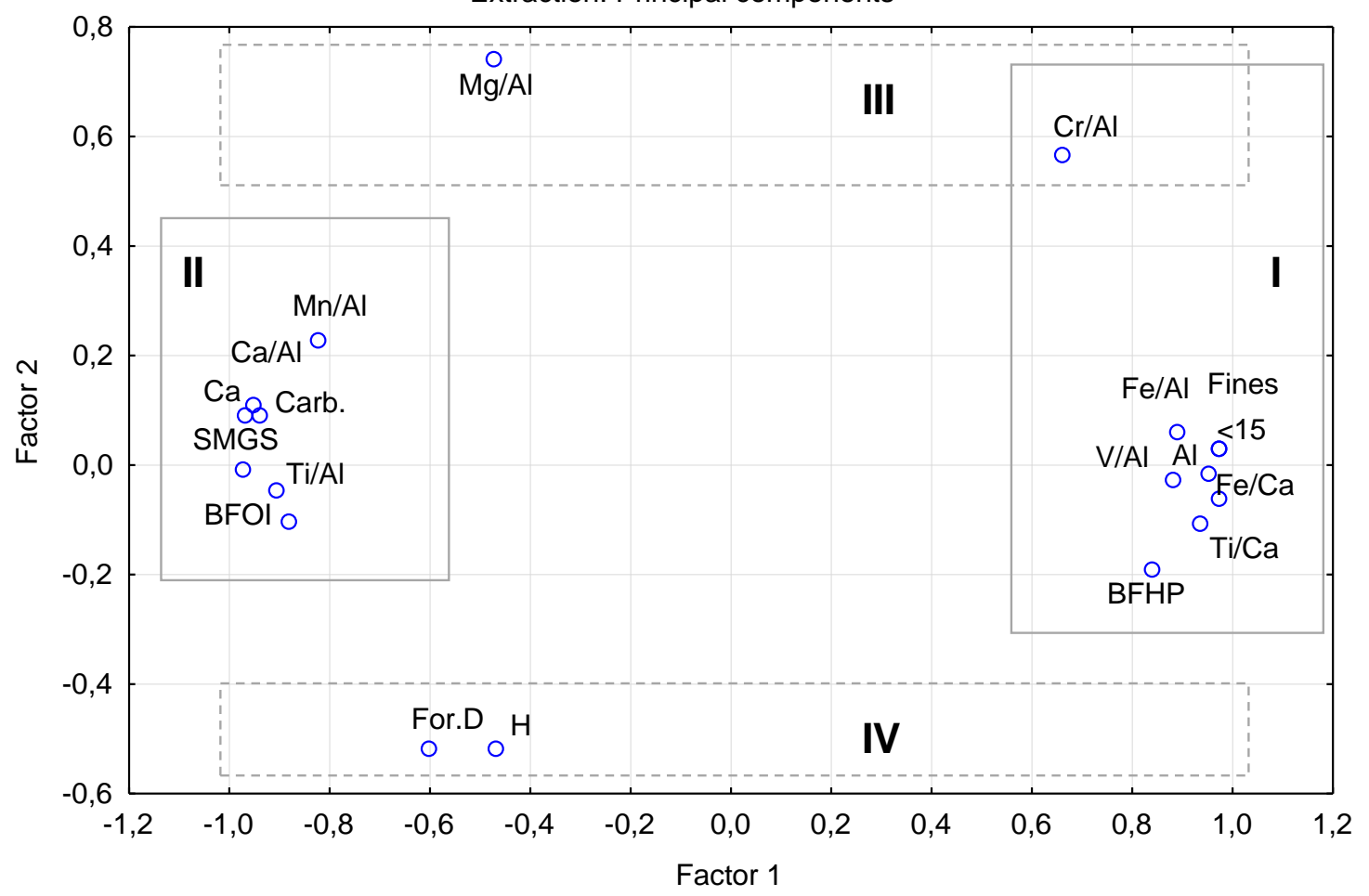

Fig. 8. Principal Component Analysis. Analysed variables in core KSGX 40, based on the following: Geochemical data (Al, Ca, Ca/Al, $\mathrm{Cr} / \mathrm{Al}, \mathrm{Fe} / \mathrm{Al}, \mathrm{Fe} / \mathrm{Ca}, \mathrm{Mg} / \mathrm{Al}, \mathrm{Mn} / \mathrm{Al}, \mathrm{Ti} / \mathrm{Al}$, Ti/Ca, V/Al; and Carb. - carbonates). Biological variables (BFHP - Benthic Foraminifera High Productivity proxy; BFOI - Benthic Foraminiferal Oxygen Index; H - Shannon Index; S - foraminiferal specific richness; and For.D - foraminifera abundance). Grain size (SMGS - sediment mean grain size; Fines - fine fraction $<63 \mu \mathrm{m}$ and $<15 \mu \mathrm{m}$, fine silt plus clay fractions).

Based on $\mathrm{V} / \mathrm{Al}$ and $\mathrm{Cr} / \mathrm{Al}$ ratios (Fig. 6a), a general decreasing trend in sediment oxygenation was identified along core 7620 , with three main phases of distinct redox conditions. The first phase refers to the time period prior to $7000 \mathrm{yr}$ cal BP and corresponds to relatively high oxygenation levels in the sediments.

During the second phase, from $7000 \mathrm{yr}$ cal BP to $\sim 4500$ yr cal BP, increasing values of $\mathrm{V} / \mathrm{Al}$ and $\mathrm{Cr} / \mathrm{Al}$ suggest oxygen depletion. This phase is marked by a conspicuous break in the $\mathrm{V} / \mathrm{Al}$ and $\mathrm{Cr} / \mathrm{Al}$ ratios from 4500 to $3000 \mathrm{yr}$ cal $\mathrm{BP}$, which indicates better oxygenation conditions in the sediments. The final phase, from $3000 \mathrm{yr}$ cal BP to present, shows increasing values of $\mathrm{V} / \mathrm{Al}$ and $\mathrm{Cr} / \mathrm{Al}$, and suggests the establishment of a period of less oxygenated conditions in surface sediments.
Sediment oxygen depletion is a stressor that can lead to the decline of benthic fauna. During these adverse phases, the abundance of foraminifera did not necessarily decrease. Some benthic foraminifera species are sensitive to oxygen depletion, but some are very resistant to such conditions (Moodley et al., 1997; Langlet et al., 2014), and can survive for several months in anoxic environments (Bernhard and Reimers, 1991; Langlet et al., 2013). Some species can live in the sediment but can move to the upper surface of sediments if pore-water does not provide adequate living conditions, as happens when they become oxygen depleted (Ernst and van der Zwaan, 2004). The evidences indicate that there has been a more drastic reduction of oxygen in the sediment in the last $2500 \mathrm{yr}$ cal BP but the water-sediment interface must have been oxygenated, due to the renewal of the water column. 
So the oxygen depletion in deeper layers of the sediment may have unaffected benthic foraminifera in that period. On the other hand, the organisms benefited from the abundance of food.

\subsubsection{Galician region}

In core KSGX40, lower values of BFHP from $\sim 4800$ to $2200 \mathrm{yr}$ cal BP are related to coarser grained sediments. This indicates a stronger hydrodynamic regime that prevented organic matter from settling to the sea floor. The higher foraminifera abundance and diversity, and BFOI values, suggest that the decay of organic matter (food) to the bottom during this period was sufficient to sustain the development of a rich and diverse benthic fauna in well-oxygenated pore waters of near surface sediments. However, according to Martins et al. (2007), the rising BFHP values in the Galician area, since $2500 \mathrm{yr}$ cal BP, primarily during $\sim 2200-1200 \mathrm{yr}$ cal BP and 500-0 yr cal BP (80-50 cm and $20-0 \mathrm{~cm})$, suggest an increase in organic carbon flux to the bottom.

In core KSGX40, lower BFOI values in the muddy intervals ( 2200-1200 yr cal BP and $\sim 500-0 \mathrm{yr}$ cal BP, $80-50$ $\mathrm{cm}$ and $20-0 \mathrm{~cm}$, respectively), increased values of $\mathrm{V} / \mathrm{Al}$, $\mathrm{Fe} / \mathrm{Al}$ and $\mathrm{Cr} / \mathrm{Al}$ and lower values of $\mathrm{Mn} / \mathrm{Al}$ are consistent with oxygen depletion. Exhaustive organic matter decay by aerobic organisms would have caused dysoxia in the sediment pore waters despite the oxygenation of the overlying water column (Martins et al., 2007).

\subsection{Evidence of sea level changes}

\subsubsection{Cabo Frio region}

The age plot of the percentage of shallow water benthic foraminifera species shows the influence of sea-level oscillations in the area where core 7620 was collected. The highest percentage of shallow water species was observed at $9370 \mathrm{yr}$ cal BP and decreased sharply until $\sim 7000 \mathrm{yr}$ cal BP; the representativeness of these species remained low until the present.

The scarcity of dating data and reliable sea-level indicators is a general characteristic of southern Brazilian shelf sea-level curves since the Last Glacial Maximum up to $7000 \mathrm{yr}$ cal BP. Most of the published papers on this subject are restricted to correlations with morphosedimentary features, such as submerged terraces correlated with global sea-level change curves, with the exception of Correa (1996).

According to Correa (op. cit.), periods of sea-level stabilization occurred at $9000 \mathrm{yr}$ cal BP (between -32 and $45 \mathrm{~m}$ ) and at $8000 \mathrm{yr}$ cal BP (between -20 and $-25 \mathrm{~m}$ ). The recent data are consistent with an age of $7955 \pm 170 \mathrm{yr}$ cal $\mathrm{BP}$, at a level of $1.4 \pm 0.5$ meters below the present sea level, as described by Martin et al. (2003).

The sea-level curves of the middle and late Holocene were originally defined by numerous reconstructions of sea level, both in space and over time, and were obtained from a database of more than 700 radiocarbon datings (Suguio et al., 1985; Angulo and Suguio, 1995).

Martin et al. (2003) produced the first reservoircorrected, astronomically calibrated sea-level change curve for a sector of the Brazilian coast. Their results indicate the occurrence of three main events of submergence of the coast (7800-5600 yr cal BP, 3700-3500 yr cal BP and 2300-2100 yr cal BP) that were staggered among periods of emergence. Conversely, Angulo et al. (2006) summarized a large data set with evidence of a progressive decline in sea level since the mid-Holocene maximum.

Regardless of which model is adopted, the mid-Holocene maximum in the study area represents an increase of approximately 3 meters above the present sea level. The time interval considered in our core samples allows us to hypothesize that the Holocene sea-level changes may have influenced the first phase of variability, which corresponds to the interval from the base of the core up to $7000 \mathrm{yr} \mathrm{cal}$ BP.

This change would represent a rise in sea level from approximately 35 meters below the present sea level up to a position similar to present levels. The potential effect of small-scale variations in sea level (less than 4 meters in either of the two models described above) is still unknown.

\subsubsection{Galician region}

The Holocene maximum transgression at the Iberian Peninsula may have occurred at approximately $7000 \mathrm{yr} \mathrm{cal}$ $\mathrm{BP}$, with a slight drop from 6900 to $2700 \mathrm{yr}$ cal BP, followed by a slight rise between $2400 \mathrm{yr}$ cal BP and the present (Zazo et al., 1996).

Sea levels reached their present position at approximately $3000 \mathrm{yr}$ cal BP (Leorri and Cearreta, 2003). However, in the last $5000 \mathrm{yr}$ cal BP, only small oscillations (Dias et al., 2000) without sufficient vertical amplitude to directly influence the benthic hydrodynamic regime of the Galicia outer shelf should have occurred. Therefore, the influence of sea level oscillations was not considered important in the sedimentary changes recorded in core KSGX40, and other oceanographic phenomena related to climate conditions were considered as 
the main factors influencing sedimentation in the Galician outer shelf since $4800 \mathrm{yr}$ cal BP (Martins et al., 2007).

\subsection{Environmental changes}

\subsubsection{Cabo Frio region}

Results from core 7620 show four phases of environmental change determined by sea-level and climatic/oceanographic conditions.

Phase I: Prior to $7000 \mathrm{yr}$ cal BP. This phase corresponds to rising sea levels from approximately $35 \mathrm{~m}$ below present levels to present levels (Correa, 1996). This phase is characterized by lower rates of sedimentation; deposition of finer sediments, with clay and silt content frequently comprising more than $90 \%$ of the grain size distribution, and relatively high values of $\mathrm{CaCO}_{3}$ and BFHP. Shallow-water benthic foraminifera concentrations agree with this low sealevel scenario. The low abundance of benthic foraminifera (Fig. 6a) also indicates instability of environmental conditions, characteristic of a coastal area.

Indicators of decreasing terrigenous input also suggest either a progressive drowning of the coast or a slight decrease in humidity. Higher values of BFHP indicate that the area had relatively high productivity. However, the benthic foraminifera assemblage composition suggests a relatively high abundance of species such as Elphidium spp. and Nonionella atlantica, which are common in organic carbon enriched sediments in transitional coastal environments in Brazil. Thus, the increase in BFHP values during this period does not correspond to higher oceanic water column productivity, due to greater sea-level upwelling but rather to a relatively high contribution of continental organic carbon.

Phase II: 7000 to 5800 yr cal BP. This interval corresponds to the end of the submergence of the Brazilian coast during the middle Holocene (Martin et al., 2003; Angulo et al., 2006). The relative abundance of shallowwater benthic foraminifera species is significantly reduced, resulting in an increased assemblage more characteristic of an open sea environment. This interval is marked by a conspicuous increase in the $\mathrm{Fe} / \mathrm{Ca}$ and $\mathrm{Ti} / \mathrm{Ca}$ ratios (Fig. 4a), a slight increase in grain size (Fig. 3a) and low rates of sediment accumulation (Fig. 9a), which coincides with the drier and warmer period described by Ledru et al. (1996). The rising sea level coupled with low river runoff resulted in nutrient impoverishment, as suggested by the decreased BFHP, indicative of declining biological productivity and low organic matter supply to the benthic fauna. This resulted in oxic conditions as indicated by the increase in $\mathrm{Cr} / \mathrm{Al}$ and $\mathrm{V} / \mathrm{Al}$ values.

Phase III: 5800 to $2500 \mathrm{yr}$ cal BP. This period of decreasing sea levels encompasses the 3700-3500 yr cal BP submergence phase identified by Martin et al. (2003). This time interval is characterized by lower values of terrigenous input proxies $(\mathrm{Fe} / \mathrm{Ca}$ and $\mathrm{Ti} / \mathrm{Ca}$ ) and productivity $(\mathrm{BFHP})$, and corresponds to the phase of dryness described by several authors (Scheel-Ybert, 2000; Scheel-Ybert et al., 2003; Pessenda et al., 2004; Sylvestre et al., 2005).

Phase IV: $2500 \mathrm{yr}$ cal BP to the present. In this period, the sea level was similar to that of the present. This uppermost interval of the core is marked by a significant increase in sedimentation rate and by the higher values of $\mathrm{BFHP}$ and redox proxies ( $\mathrm{Cr} / \mathrm{Al}$ and $\mathrm{V} / \mathrm{Al})$. These proxies indicate a higher supply of organic matter coupled with the intensification of upwelling conditions.

Contrary to what was found in core KSGX40, the sediments in core 7620 were coarser during this period. This coarseness suggests that other hydrodynamic factors, such as the meandering strength of the Brazil Current, which depends on the dynamics of the South Atlantic Ocean as a whole, and prevailing winds, may be important influences in the upwelling process off Cabo Frio (Campos et al., 2000).

\subsubsection{Galician region}

The sediments of core KSGX40 deposited during the period $\sim 4800-2500 \mathrm{yr}$ cal BP were the result of extreme winters associated with the following conditions: i) large river runoff and large sediment loads ii) resuspension of sediments associated with SW storms and large waves and iii) conditions favorable to downwelling, promoting northward and offshore transport through the bottom boundary layer, which influenced the prevalence of a strong hydrodynamic regime (Martins et al., 2007). The enforcement of southerly winds associated with precipitation is typical of negative phases of North Atlantic Oscillations (NAO).

After 2500 yr cal BP, but especially between $\sim 2200-1200$ yr cal BP and 500-0 yr cal BP, the muddy sections were formed by increasing upwelling events, caused by the stronger northerly winds coupled with a stratified shelf and a weak benthic hydrodynamic regime (Martins et al., 2007). 
A) Core 7620
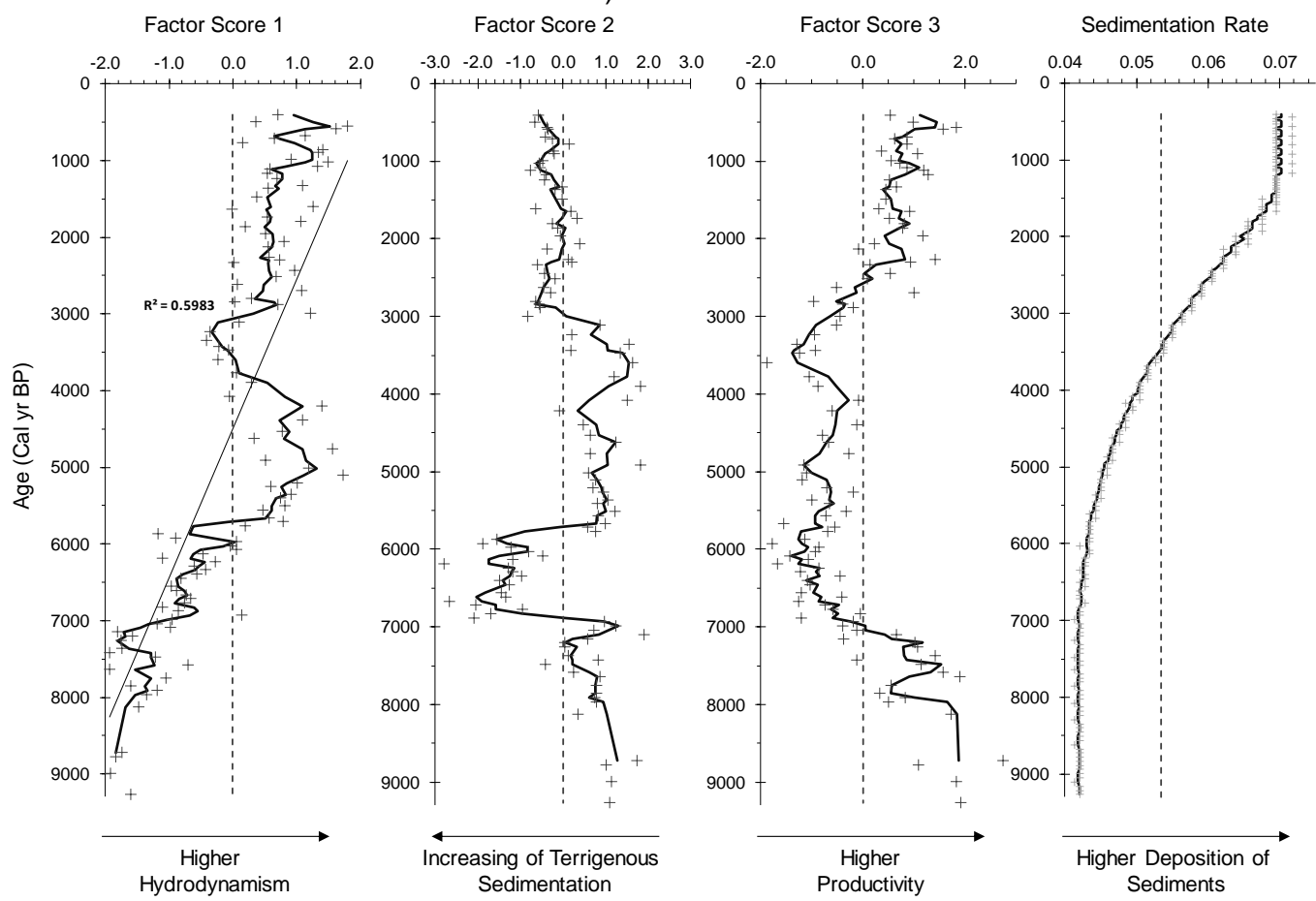

B) Core KSGX 40

Factor Score 1

Factor Score 2
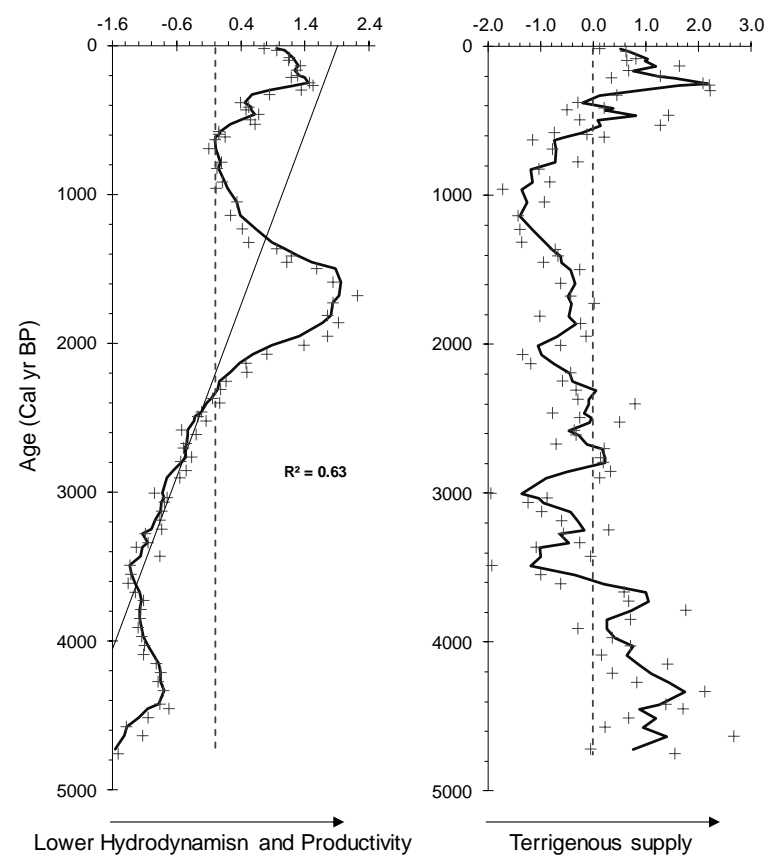

Fig. 9. Temporal evolution of the first three factor score values of PCA analysis in core 7620, and of the first two factor score values in core KSGX 40. In order to facilitate the interpretation of sediment input in core 7620, the sedimentation rate values along this core are presented. The factors that may explain the data variability in each plot are also given below each graph. Core chronology, data (points), and the data mean value and mean moving averages based on three results (grey line) are represented in each depth plot. The regression line with $\mathrm{R}^{2}$ value is also presented in some graphs. 


\subsection{Paleoclimatic implications}

\subsubsection{Cabo Frio region}

According to the General Circulation Model presented by Cruz et al. (2009), the Cabo Frio area constitutes a transition between two main paleoclimatic regions in South America. No major climatic variability between $6000 \mathrm{yr}$ BP and the present was expected to have occurred when compared to the last glacial period. Nevertheless, our results, together with previous observations from other authors (e.g., Scheel-Ybert, 2000; Sylvestre et al., 2005; Laslandes et al., 2006), indicate the occurrence of conspicuous changes in environmental conditions that affected sedimentation patterns and upwelling phenomena.

Stronger upwelling during the last $2500 \mathrm{yr}$ cal BP in Cabo Frio coincides with stronger upwelling in the NW Iberian Margin (PCA Factor 1; Fig. 9b). In the NW Iberian Margin the upwelling is associated with a prevalence of northerly winds and relatively dry weather conditions typical of positive phases of North Atlantic Oscillations (NAO).

According to Versteegh (2005), the movement of the ITCZ is likely related to solar activity. The anomalous southward displacement of the ITCZ is linked to a strengthening of N-NE winds, favorable to upwelling. The abrupt changes observed in the millennial-scale variation from productivity-derived factors, and the proposed wind cause-effect relationship, is also consistent with the recent work of Stager et al. (2005). These authors discussed tropical sun-climate associations during the last millennium that were subject to abrupt sign reversals, based on a diatom series from Lake Victoria, East Africa with 1-6 year resolution.

Examination of core 7620 Factor Score 3 (organic matter input due to oceanic productivity), associated with variability in the last $7000 \mathrm{yr}$ cal BP, reveals a multi-millennial modulation that could be related to southward latitudinal shifts of the ITCZ, consistent with the variations shown by Haug et al. (2001) for the Cariaco Basin over the last $3000 \mathrm{yr}$ cal BP.

\subsubsection{Intensification of the upwelling in Cabo Frio and in the Galician Area}

The sedimentary records analyzed in this work indicate a synchronous intensification of upwelling in both Cabo Frio $(\mathrm{SH})$ and the Galician Area (NH) over the last $2500 \mathrm{yr}$ cal BP. Both studies associate stronger upwelling with arid conditions, and establish a strong correlation between upwelling and NE winds. However, the upwelling system in the Cabo Frio region is linked with changes in the ITCZ position, whereas in the Galician area, it is coupled with NAO indexes. A common external forcing probably explains these inter-hemispheric phase changes. Accordingly, we cannot discard the hypothesis that solar activity could have had a direct or indirect influence in both systems, thereby impacting atmospheric and/or oceanographic climate conditions.

Bond events, for instance have been correlated to solar activity variation (Bond et al., 2001). Debret et al. (2009) suggested a change in the main global climatic driving mechanisms from external (i.e. solar insolation) to internal (i.e. oceanic-atmospheric coupling, e.g. ENSO) forcing at ca. 5 kyr cal BP.

Cheng et al. (2012), in a paper comparing global monsoon systems, also proposed that some mechanisms amplify solar variations, such as the atmospheric-oceanic climatic systems related to the ENSO. These forces may explain the results obtained in both regions. They probably induced alterations simultaneously in ENSO and NAO in the Southern and Northern hemispheres respectively.

\section{Conclusions}

Despite the existence of local differences and particularities in the Cabo Frio and Galician upwelling systems capable of inducing changes in the sedimentary records in each region, an intensification of upwelling was recorded in both study areas over the last $2500 \mathrm{yr}$ cal BP. The wind regime that determines changes in the upwelling pattern for each region is controlled by different atmospheric features. The Galician system is influenced by the NAO indexes, and the Cabo Frio system is influenced by the average position of the ITCZ. Therefore, the in-phase inter-hemispheric changes in the two upwelling regions, the Southeast Brazilian and NW Iberian Margins, recorded in both cores provides a strong indication that solar forcing affected both oceanic-atmospheric systems, with implications over the ITCZ latitudinal position and the NAO indexes.

\section{Acknowledgments}

The authors wish to thank Mr. Marcelo Rodrigues, Samara Cazzoli Goya, Clodoaldo Vieira Tolentino and Edilson Faria for their help in the sediment sampling and laboratory analyses. Thanks are also due to the crew of the R.V. "Prof. W. Besnard" and to Cleveland Jones for the manuscript proofreading. This paper is a contribution to the IGCP526 Project (Risks, Resources, Record of the Past on the Continental Shelves). Financial support was provided by Fapesp (process 03/10740-0) and CNPq (300381/2004-2), and through UID/GEO/04035/2013 (FCT, Portugal). 


\section{References}

Álvarez, M.C., Flores, J.A., Sierro, F.J., Diz, P., Francés, G., Pelejero, C., Grimalt, J., 2005. Millennial surface water dynamics in the Ría de Vigo during the last 3000 years as revealed by coccoliths and molecular biomarkers. Palaeogeography Palaeoclimatology Palaeoecology 218, 1-13.

Angulo, R.J., Lessa, G.C., Souza, M.C., 2006. A critical review of mid- to late-Holocene sea-level fluctuations on the eastern Brazilian coastline. Quaternary Science Reviews 5, 486-506.

Angulo, R.J., Souza, M.C., Reimer, J., Sasaoka, S.K., 2005. Reservoir effect of the southern and southeastern Brazilian coast. Radiocarbon 47, 67-73.

Angulo, R.J., Suguio, K., 1995. Re-evaluation of the Holocene sealevel maxima for the State of Parana, Brazil. Palaeogeography Palaeoclimatology Palaeoecology 113, 385-393.

Arz, H.W., Pätzold, J., Wefer, G., 1998. Correlated millennial-scale changes in surface hydrography and terrigenous sediment yield inferred from last-glacial marine deposits off northeastern Brazil. Quaternary Research 50, 157-166.

Barron, J.A., Bukry, D., Bischoff, J.L., 2004. High resolution paleoceanography of the Guaymas Basin, Gulf of California, during the past 15000 years. Marine Micropaleontology 50, 185207.

Bartels-Jónsdóttir, H.B., Knudsen, K.L., Abrantes, F., Lebreiro, S., Eiríksson, J., 2006. Climate variability during the last 2000 years in the Tagus Prodelta, western Iberian Margin: Benthic foraminifera and stable isotopes. Marine Micropaleontology 59, 83-103.

Barton, E.D., Aristeguí, J., Tett, P., Canton, M., Garcia-Braun, J., Hernandez-Leon, S., Nykjaer, L., Almeida, C., Almunia, J., Ballesteros, S., Basterretxea, G., Escanez, J., Garcia-Weill, L., Hernandez-Guerra, A., Lopez-Laatzen, F., Molina, R., Montero, M.F., Navarro-Perez, E., Rodriguez, J.M., van Lenning, K., Vélez, H., Wild, K., 1998. The transition zone of the Canary Current upwelling region, Progress in Oceanography 41, 455504.

Behling, H., 1998. Late Quaternary vegetational and climatic changes in Brazil. Review of Palaeobotany and Palynology 99, 143-156.

Behling, H., 1997. Late Quaternary vegetation, climate and fire history of the Araucaria forest and campos region from Serra Campos Gerais, Paraná State (South Brazil). Review of Palaeobotany and Palynology 97, 109-121.

Bender, V.B., Hanebuth, T.J.J., Chiessi, C.M., 2013. Holocene shifts of the Subtropical Shelf Front off southeastern South America controlled by high and low latitude atmospheric forcings. Paleoceanography 28, 481-490. doi:10.1002/palo.20044

Bernárdez, P., Gonzalez-Álvarez, R., Francés, G., Prego, R., Bárcena, M.A., Romero, O.E., 2008. Late Holocene history of the rainfall in the NW Iberian peninsula - Evidence from a marine record. Journal of Marine Systems 72, 366-382.

Bernhard, J.M., Reimers, C.E., 1991. Benthic foraminiferal population fluctuations related to anoxia: Santa Barbara Basin. Biogeochemistry 15, 127-149.
Bianchi, G.G., Mccave, I.N., 1999. Holocene periodicity in North Atlantic climate and deep-ocean flow south of Iceland. Science 397, 515-517.

Böhnecke, G., 1994. Temperature, salinity and density of the surface waters of the Atlantic Ocean. In: Scientific Results of the German Atlantic Expedition of the Research Vessel Meteor, 1925-1927, Washington: National Science Foundation, vol 5. doi:10.1002/(SICI)1097-0088(19970330)17:4<455::AID-

JOC133>3.0.CO;2-A

Bond, G.C., Kromer, B., Beer, J., Muscheler, R., Evans, M.N., Showers, W., Hoffmann, S., Lotti-Bond, R., Hajdas, I., Bonani, G., 2001. Persistent solar influence on North Atlantic climate during the Holocene, Science, 294, 2130-2133.

Bond, G., Showers, W., Cheseby, M., Lotti, R., Almasi, P., Demenocal, P., Priore, P., Cullen, H., Hajdas, I., Bonani, G., 1997. A pervasive millennial-scale cycle in North Atlantic Holocene and glacial climates. Science 278, 1257-1266.

Burone, L., Venturini, N., Sprechmann, P., Valente, P., Muniz, P., 2006. Foraminiferal responses to polluted sediments in the Montevideo coastal zone, Uruguay. Marine Pollution Bulletin 52, 61-73.

Campos, E.J.D., Velhote, D., Silveira, I.C.A., 2000. Shelf break upwelling driven by Brazil Current cyclonic meanders. Geophysical Research Letters 27, 751-754.

Castro, B.M., Miranda, L.B., 1998. Physical oceanography of the western Atlantic continental shelf located between $4^{\circ} \mathrm{N}$ and $34^{\circ} \mathrm{S}$ - coastal segment (4, W). In: Robinson, A.R., Brink, K.H. (eds.), The Sea. New York. John Wiley, pp. 209-251.

Claussen, M., Claussen, M., Kubatzki, C., Brovkin, V., Ganopolski, A., Hoelzmann, P., Pachur, H.J., 1999. Simulation of an abrupt change in Saharan vegetation in the mid-Holocene. Geophysical Research Letters 26, 2037-2040.

Cheng, H., Sinha, A., Wang, X.F., Cruz, F.W., Edwards, R.L., 2012. The Global Paleomonsoon as seen through speleothem records from Asia and the Americans. Climate Dynamics 39, 1045-1062. doi 10.1007/s00382-012-1459-0

Correa, I.C.S., 1996. Les variations du niveau de la mer durant les derniers 17500 ans BP: l'exemple de la plate-forme continentale du Rio Grande do Sul - Brésil. Marine Geology 130, 163-178.

Cruz, F.W., Vuille, M., Burns, S.J., Wang, X., Cheng, H., Werner, M., Edwards, L., Karmann, I., Auler, A.S., Nguyen, H., 2009. Orbitally driven east-west antiphasing of South American precipitation. Nature Geoscience 2, 210-214. DOI: 10.1038/NGEO444

D’Arrigo, R.S., Cook, E.R., Jacoby, G.C., 1996. Annual to decadalscale variations in northwest Atlantic sector temperatures inferred from Labrador tree rings. Canadian Journal of Forest Research 26, 143-148.

Debret, M., Sebag, D., Crosta, X., Massei, N., Petit, J.-R., Chapron, E., Bout-Roumazeilles, V., 2009. Evidence from wavelet analysis for a mid-Holocene transition in global climate forcing. Quaternary Science Reviews 28, 2675-2688.

Dias, J.M.A., Jouanneau, J.M., Gonzalez, R., Araújo, M.F., Drago, T., Garcia, C., Oliveira, A., Rodrigues, A., Vitorino, J., Weber, O., 2002a. Present day sedimentary processes on the northern Iberian shelf. Progress in Oceanography 52, 249-259. 
Dias, J.M.A., Gonzalez, R., Garcia, C., Diaz-del-Rio, G., $2002 b$. Sediment distribution patterns on the Galicia-Minho continental shelf. Progress in Oceanography 52, 215-231.

Dias, J.M.A., Boski, T., Rodrigues, A., Magalhães, F., 2000. Coast line evolution in Portugal since the Last Glacial Maximum until present - a synthesis. Marine Geology 170, 177-186.

Dias, J.M.A., Nittrouer, C., 1984. Continental shelf sediments of northern Portugal. Continental Shelf Research 3, 147-165.

Diester-Haass, L., 1978. Sediments as indicators of upwelling. In: Boje, R, and Tomczak, M. (eds.) Upwelling Ecosystems, Berlin, Springer-Verlag, pp. 261-281.

Diz, P., Francés, G., Pelejero, C., Grimalt, J.O., Vilas, F., 2002. The last 3000 years in the Ría de Vigo (NW Iberian Margin): climatic and hydrographic signals. Holocene 12, 459-468.

Emilsson, I., 1961. The shelf and coastal waters off southern Brazil. Boletim do Instituto Oceanográfico 11, 101-112.

Emilsson, I., 1959. Alguns aspectos físicos e químicos das águas marinhas brasileiras. Ciência e Cultura 11, 44-54.

Ernst, S., V Der Zwaan, B., 2004. Effects of experimentally induced raised levels of organic flux and oxygen depletion on a continental slope benthic foraminiferal community. Deep-Sea Research I, 51, 1709-1739.

Fiúza, A.F.G., Hamann, M., Ambar, I., Dıaz del Rı, G., Gonzalez, N., Cabanas, J.M., 1998. Water masses and their circulation off western Iberia during May 1993. Deep-Sea Research Part I 45: 1127-1160.

Fiúza, A.F.G., 1984. Hidrologia e dinâmica das águas costeiras de Portugal. PhD thesis, Universidade de Lisboa, Portugal (in Portuguese).

Fraga, F., 1981. Upwelling off the Galician coast, Northwest of Spain. In: Richards, F.A. (ed), Coastal Upwelling, Washington, DC: American Geophysical Union, pp. 176-182.

Frouin, R., Fiúza, A.F.G., Ambar, I. and Boyd, T.J. 1990. Observations of a poleward surface current off the coasts of Portugal and Spain during winter. Journal of Geophysical Research 95, 679-691.

Gagan, M.K., Ayliffe, L.K., Hopley, D., Cali, J.A., Mortimer, G.E., Chappell, J., Mcculloch, M.T., Head, M.J., 1998. Heat, temperature and surface-ocean water balance of the midHolocene tropical western Pacific. Science 279, 1014-1018.

Gaiero, D., Depetris, P.J., Probst, J.L., Bidart, S.M., Leleyter, L. 2004. The signature of river- and wind-borne materials exported from Patagonia to the southern latitudes: a view from REEs and implications for paleoclimatic interpretations. Earth and Planetary Science Letters 219, 357-376.

Garcia, M.J., Oliveira, P.O., Siqueira, E., Fernandes, R.S., 2004. A Holocene vegetational and climatic record from the Atlantic rainforest belt of coastal State of São Paulo, SE Brazil. Review of Palaeobotany and Palynology 131, 181-199.

Gilli, A., Ariztegui, D., Anselmetti, F.S., Mckenzie, J.A., Markgraf, V., Hajdas, I., Mcculloch, R.D., 2005. Mid-Holocene strengthening of the Southern Westerlies in South America Sedimentological evidences from Lago Cardiel, Argentina (49 $\mathrm{S}$ ). Global and Planetary Change 49, 75-93.

González-Rodriguez, E., 1990. A ressurgência de Cabo Frio (RJ, Brasil): Fertilidade e Fatores Nutricionais Limitantes da
Biomassa Fitoplanctônica. Revista Brasileira de Biociências 51, 471-486.

Gyllencreutz, R., Mahiques, M.M., Alves, D.V.P., Wainer, I.K.C., 2010. Mid- to late- Holocene paleoceanographic changes on the southeastern Brazilian shelf based on grain size records. The Holocene 20, 863-875. Doi:10.1177/0959683610365936.

Haslett, S.K., Davies, C.F.C., 2006. Late Quaternary climate-ocean changes in western North Africa: offshore geochemical evidence. Transactions of the Institute of British Geographers 31, 34-52.

Haug, G.H., Hughen, K.A., Sigman, D.M., Peterson, L.C., Röhl, U., 2001. Southward migration of the intertropical convergence zone through the Holocene. Science 293, 1304-1308.

Haynes, R., Barton, E.D., Pilling, I., 1993. Development, persistence, and variability of upwelling filaments off the Atlantic Coast of the Iberian Peninsula. Journal of Geophysical Research 98, 22681-22692.

Heegard, E., Birks, H.J.B., Telford, R.J., 2005. Relationships between calibrated ages and depth in stratigraphical sequences: an estimation procedure by mixed-effect regression. Holocene 15, 612-618.

Hughen, K.A., Baillie, M.G.L., Bard, E., Beck, J.W., Bertrand, C.J.H., Blackwell, P.G., Buck, C.E., Burr, G.S., Cutler, K.B., Damon, P.E., Edwards, R.L., Fairbanks, R.G., Friedrich, M., Guilderson, T.P., Kromer, B., McCormac, G., Manning, S., Ramsey, C.B., Reimer, P.J., Reimer, R.W., Remmele, S., Southon, J.R., Stuiver, M., Talamo, S., Taylor, F.W., van der Plicht, J., Weyhenmeyer, C.E., 2004. Marine04 marine radiocarbon age calibration, 0-26 cal kyr BP. Radiocarbon 46, 1059-1086.

Hurrell, J.W., Dickson, R.R., 2004. Chapter 2: Climate variability over the North Atlantic. In: Stenseth, N.C., Ottersen, G., Hurrell, J.W., Belgrano, A. (eds) Marine Ecosystems and Climate Variation - the North Atlantic. Oxford University Press.

Hurrell, J.W., Kushnir, Y., Ottersen, G., Visbeck, M., 2003. An overview of the North Atlantic oscillation. Geophysical Monograph 134, 1-35.

Ikeda, Y., Miranda, L.B., Rock, N., 1974. Observations on stages of upwelling in the region of Cabo Frio (Brazil), as conducted by continuous surface temperature and salinity measurements. Boletim do Instituto Oceanográfico 23, 33-46.

Jouanneau, J.M., Weber, O., Drago, T., Rodrigues, A., Oliveira, A., Dias, J.M.A., Garcia, C., Schmidt, S., Reyss, J.L., 2002. Recent sedimentation and sedimentary budgets on the western Iberian shelf. Progress in Oceanography 52, 261-275.

Julivert, M., Fontbote, J. M., Ribeiro, A., Conde, L., 1980. Mapa tectonico de la Península Ibérica y Baleares (scale 1/1000 000) - explicative memory. Institute Geologico y Geominero de España, Madrid.

Langlet, D., Baal, C., Geslin, E., Metzger, E., Zuschin, M., Riedel, B., Risgaard-Petersen, N., Stachowitsch, M., Jörissen, F.J., 2014. Foraminiferal species responses to in situ, experimentally induced anoxia in the Adriatic Sea. Biogeosciences 11, 17751797.

Langlet, D., Geslin, E., Baal, C., Metzger, E., Lejzerowicz, F., Riedel, B., Zuschin, M., Pawlowski, J., Stachowitsch, M., Jörissen, F.J., 2013. Foraminiferal survival after long-term in situ experimentally induced anoxia. Biogeosciences, 10, 7463-7480. 
Laslandes, B., Sylvestre, F., Sifeddine, A., Turcq, B., Albuquerque, A.L.S., Abrão, J., 2006. Enregistrement de la variabilité hydroclimatique au cours des 6500 dernières années sur lê littoral de Cabo Frio (Rio de Janeiro, Brésil) Comptes Rendues. Geoscience 338, 667-675.

Ledru, M.P., Salgado-Labouriau, M.L., Lorscheitter, M.L., 1998. Vegetation dynamics in southern and central Brazil during the last 10,000 yr BP. Review of Palaeobotany and Palynology 99, 131-142.

Ledru, M.P., Braga, P.I.S., Soubiés, F., Fournier, M., Martin, L., Suguio, K., Turcq, B., 1996. The last 50,000 years in the Neotropics (Southern Brazil): evolution of vegetation and climate. Palaeogeography Palaeoclimatology Palaeoecology 123, 239-257.

Leorri, E., Cearretam, A., 2004. Holocene environmental development of the Bilbao estuary, northern Spain: sequence stratigraphy and foraminiferal interpretation. Marine Micropaleontology 51, 75-94.

López-Jamar, E., Cal, R.M., González, G., Hanson, R.B., Rey, J., Santiago, G., Tenore, K.R., 1992. Upwelling and outwelling effects on the benthic regime of the continental shelf off Galicia, NW Spain. Journal of Marine Research 50, 465-488.

Mahiques, M.M., Sousa, S.H.M., Burone, L., Nagai, R.H., Silveira, I.C.A., Figueira, R.L., Soutelino, R.G., Ponsoni, L., Klein, D.A., 2011. Radiocarbon geochronology of the sediments of the São Paulo Bight (southern Brazilian upper margin). Anais da Academia Brasileira de Ciências 83, 817-834.

Mahiques, M.M., Wainer, I.K.C., Burone, L., Nagai, R., Sousa, S.H.M., Figueira, R.C.L., Silveira, I.C.A., Bícego, M.C., Alves, D.P.V., Hammer, Ø., 2009. A high-resolution Holocene record on the Southern Brazilian shelf. Paleoenvironmental implications. Quaternary International 206, 52-61.

Mahiques M.M., Fukumoto, M.M., Silveira, I.C.A., Figueira, R.C.L., Bícego, M.C., Lourenço, R.A., Sousa, S.H.M., 2007. Sedimentary changes on the South-eastern Brazilian upper slope during the last 35,000 years. Anais da Academia Brasileira de Ciências 79, 171-181.

Mahiques, M.M., Bícego, M.C., Silveira, I.C.A., Sousa, S.H.M., Lourenço, R.A. and Fukumoto, M.M. 2005. Modern sedimentation in the Cabo Frio upwelling system, Southeastern Brazilian shelf. Anais da Academia Brasileira de Ciências 77, 535548.

Mahiques, M.M., Tessler, M.G., Ciotti, A.M., Silveira, I.C.A., Sousa, S.H.M., Figueira, R.L., Tassinari, C.C.G., Furtado, V.V., Passos, R.F., 2004. Hydrodynamically-driven patterns of recent sedimentation in the shelf and upper slope off southeast Brazil. Continental Shelf Research 24, 1685-1697.

Margalef, R. 1978. Phytoplankton communities in upwelling areas: The example of NW Africa. Oecologia Aquatica 3, 97-132.

Marshall, J., Kushnir, Y., Battisti, D., Chang, P., Hurrel, J., McCartney, M., Visbeck, M., 1997. A white paper on Atlantic climate variability. Available at: http://geoidmitedu/accp/avehtmlhtml

Martin, L., Dominguez, J.M.L., Bittencourt, A.C.S.P., 2003. Fluctuating Holocene sea levels in eastern and southeastern
Brazil: Evidence from multiple fossil and geometric indicators. Journal of Coastal Research 19, 101-124.

Martin, L., Flexor, J.M., Valentin, J.L., 1988. Influence du phenomene Oceanique Pacifique 'El Niño' sur l'upwelling et le climat de la region de Cabo Frio, sur la côte bresilienne de l'Etat de Rio de Janeiro. Les Comptes Rendus de l'Academie des Sciences de Paris 307, 1101-105.

Martin, L., Absy, M.L., Flexor, J.M., Fournier, M., Mourguiart, P., Sifeddine, A., Turcq, B., 1993. Southern oscillation signal in South American palaeoclimatic data of the last 7000 years. Quaternary Research 39, 338-46.

Martins, V., Figueira, R.C.L., França, E.J., de Lima Ferreira, P.A., Martins, P., Santos, J.F., Dias, J.A., Laut, L.L.M., Soares, A.M., da Silva, E.F., Rocha, F., 2012. Sedimentary Processes on the NW Iberian Continental Shelf since the Little Ice Age Estuarine. Coastal and Shelf Science 102, 48-59.

Martins, V., Dubert, J., Jouanneau, J-M., Weber, O., Silva, E.F., Patinha, C., Alveirinho Dias, J.M., Rocha, F. 2007. A multiproxy approach of the Holocene evolution of shelf-slope circulation on the NW Iberian Continental Shelf. Marine Geology 239, 118.

Martins, V., Jouanneau, J-M., Weber, O., Rocha, F., 2006. Tracing the late Holocene evolution of the NW Iberian upwelling system. Marine Micropaleontology 59, 35-55.

Martins, V., Jouanneau, J-M., Weber, O., Patinha, C., Silva, E.F., Terroso, D., Dias, J.M.A., Rocha, F., 2005. Late Holocene evolution of redox state of the sediments of Galicia Mud Deposit (outer continental shelf). Cuadernos do Laboratorio Xeolóxico de Laxe 30, 99-124.

Mayewski, P.A., Rohling, E.E., Stager, J.C., Karlén, W., Maasch, K.A., Meeker, L.K., Meyerson, E.A., Gasse, F., van Kreveld, S., Holmgren, K., Lee-Thorp, J., Rosqvist, G., Rack, F., Staubwasser, M., Schneider, R.R., Steig, E.J., 2004. Holocene climate variability. Quaternary Research 62, 243-255.

Miranda, L.B., Castro, B.M., 1979. Condições do movimento geostrófico das águas adjacentes a Cabo Frio (RJ). Boletim do Instituto Oceanográfico 28, 79-93.

Moodley, L., van der Zwaan, G.J., Herman, P.M.J., Kempers, L., van Breugel, P., 1997. Differential response of benthic meiofauna to anoxia with special reference to Foraminifera (Protista: Sarcodina). Marine Ecology-Progress Series 158, 151163.

Moreno, A., Cacho, I., Canals, M., Grimalt, J.O., Sanchez-Vidal, A., 2004. Millenial-scale variability in the productivity signal from the Alboran Sea record, Western Mediterranean Sea. Palaeogeography Palaeoclimatology Palaeoecology 211, 205219.

Morford, J.L, Emerson, S., 1999. The geochemistry of redox sensitive trace metals in sediments. Geochimica et Cosmochimica Acta 63, 1735-1750.

Moros, M., Endler, K.R., Lackschewitz, S., Wallrabe-Adams, H-J., Mienert, J., Lemke, W., 1997. Physical properties of Reykjanes Ridge sediments and their linkage to high-resolution Greenland Ice Sheet Project 2 ice core data. Paleoceanography 12, 687-695. 
Moy, C.M., Seltzer, G.O., Rodbell, D.T., Anderson, D.M., 2002. Variability of El Niño/Southern Oscillation activity at millennial timescales during the Holocene epoch. Nature 420, 162-165

Nagai, R.H., Sousa, S.H.M., Burone, L., Mahiques, M.M., 2009. Paleoproductivity changes during the Holocene in the inner shelf of Cabo Frio, southeastern Brazilian continental margin: Benthic foraminifera and sedimentological proxies. Quaternary International 206, 62-71.

O’brien, S., Mayewski, P.A., Meeker, L.D., Meese, D.A., Twickler, M.S., Whitlow, S.I., 1995. Complexity of Holocene climate as reconstructed from a Greenland ice core. Science 270, 19621964.

Parsons, L.S, Lear, W.H., 2001. Climate variability and marine ecosystem impacts: a North Atlantic perspective. Progress in Oceanography 49, 167-188.

Peliz, A., Dubert, J., Haidvogel, D.B., Le Cann, B., 2003. Generation and unstable evolution of a density-driven Eastern Poleward Current: The Iberian Poleward Current. Journal of Geophysical Research $108 \quad$ C8, 3268. doi:10.1029/2002JC001443.

Pessenda, L.C.R., Gouveia, S.E.M., Aravena, R., Boulet, R., Valencia, E.P.E., 2004. Holocene fire and vegetation changes in southeastern Brazil as deduced from fossil charcoal and soil carbon isotopes. Quaternary International 114, 35-43.

Pflaumann, U. 1980. Variations of the surface water temperatures along the eastern North Atlantic continental margin (sediment surface samples, Holocene climatic optimum, and Last Glacial Maximum). Palaeoecology of Africa 12, 191-212.

Prego, R., Barciela, C., Varela, M., 1999. Nutrient dynamics in the Galician coastal area (Nortwestern Iberian Peninsula): Do the Rias Bajas receive more nutrient salts than the Rias Altas? Continental Shelf Research 19, 317-334.

Prego, R., Bao, R., 1997. Upwelling influence on the Galician coast: silicate in shelf water and underlying surface sediments. Continental Shelf Research 17, 307-318.

Razik, S., Chiessi, C.M., Romero, O.E., von Dobeneck, T., 2013. Interaction of the South American Monsoon System and the Southern Westerly Wind Belt during the last 14 kyr. Palaeogeography, Palaeoclimatology, Palaeoecology 374, 28-40.

Rey, J., 1990. Relación Morfosedimentaria entre la Plataforma Continental de Galicia y las Rias Bajas y su Evolución durante el Cuaternario. Doctoral thesis, Complutense University of Madrid, Madrid, 397 pp.

Rey, J., Diaz del Rio, V., 1987. Structure of recent sedimentary units in the Galician continental shelf. Cuadernos do Laboratorio Xeolóxico de Laxe 12, 35-45.

Rodbell, D., Seltzer, G.O., Anderson, D.M., Enfield, D.B., Abbott, M.B., Newman, J.H., 1999. A high-resolution 15000 year record of El Nino driven alluviation in southwestern Ecuador. Science 283, 516-520.

Rodwell, M.J., Rowell, D.P., Folland, C.K., 1999. Oceanic forcing of the wintertime North Atlantic Oscillation and European climate. Nature 398, 320-323

Rohling, E.J., De Rijk, S., 1999. Holocene climate optimum and last glacial maximum in the Mediterranean: the marine oxygen isotope record. Marine Geology 153, 57-75.
Sandweiss, D.H., Richardson III, J.B., Reitz, E.J., Rollins, H.B.R. and Maasch, K.A. 1996. Geoarcheological evidence from Peru for a 5000 years BP onset of El Nino. Science 273, 1531-1533.

Scheel-Ybert, R., Gouveia, S.E.M., Pessenda, L.C.R., Aravena, R., Coutinho, L.M. and Boulet, R. 2003. Holocene palaeoenvironmental evolution in the São Paulo state (Brazil), based on anthracology and soil 13C analysis. Holocene 13: 7381.

Scheel-Ybert, R. 2000. Vegetation stability in the southeastern Brazilian coastal area from 5500 to $140014 \mathrm{C}$ yr BP deduced from charcoal analysis. Review of Palaeobotany and Palynology 110: 111-138.

Shannon, C.E. 1948. A mathematical theory of communication. Bell System Technical Journal 27: 379-423.

Shulmeister, J., Rodbell, D.T., Gagan, M.K. and Seltzer, G.O. 2006. Inter-hemispheric linkages in climate change: paleoperspectives for future climate change. Climate of the Past 2: 167-185.

Silva, P.C.M., Rodrigues, R.F., 1966. Modificações na estrutura vertical das águas sobre a borda da plataforma continental por influência do vento. Notas Técnicas do Instituto de Pesquisas da Marinha 35, 1-13.

Soares, A.M., 1989. Efeito de reservatório oceânico nas águas costeiras de Portugal Continental. ICEN-LNETI, Departamento de Quimica, 135 pp.

Solomon, S., Qin, D., Manning, M., Chen, Z., Marquis, M., Averyt, K.B., Tignor, M., Miller, H.L., 2007. Climate Change 2007. The Physical Science Basis Contribution of Working Group I to the Fourth Assessment Report of the Intergovernmental Panel on Climate Change. Cambridge, United Kingdom and New York, NY, Cambridge University Press, 996 pp.

Stager, J.C., Ryves, D., Cumming, B.F., Meeker, L., Beer, J., 2005. Solar variability and the levels of Lake Victoria, East Africa, during the last millennium. Journal of Paleolimnology 33, 243 251.

Suguio, K., Martin, L., Bittencourt, A.C.S.P., Dominguez, J.M.L., Flexor, J.M., Azevedo, A.E.G., 1985. Flutuações do nível do mar durante o Quaternário superior ao longo do litoral brasileiro e suas implicações na sedimentação costeira. Revista Brasileira de Geociências 15, 273-286.

Sun, Y.B., Wu, F., Clemens, S.C., Oppo, D.W., 2008. Processes controlling the geochemical composition of the South China Sea sediments during the last climatic cycle. Chemical Geology 257, 243-249.

Sylvestre, F., Sifeddine, A., Turcq, B., Gil, I.M., Albuquerque, A.L.S., Lallier-Vergès, E., Abrão, J., 2005. Hydrological changes related to the variability of tropical South American climate from the Cabo Frio lagoonal system (Brazil) during the last 5000 years. Holocene 15, 625-630.

Tarasov, P., Dorofeyuk, N., Metel'Tseva, E., 2000. Holocene vegetation and climate changes in Hoton-Nur Basin, northwest Mongolia. Boreas 29, 117-126.

Tarasov, P., Webb III, T., Andreev, A.A., Afanas'eva, N.B., Berezina, N.A., Bezusko, L.G., Blyakharchuk, T.A., Bolikhovskaya, N.S., Cheddadi, R., Chernavskaya, M.M., Chernova, G.M., Dorofeyuk, N.I., Dirksen, V.G., Elina, G.A., 
Filimonova, L.V., Glebov, F.Z., Guiot, J., Gunova, V.S., Harrison, S.P., Jolly, D., Khomutova, V.I., Kvavadze, E.V., Osipova, I.M., Panova, N.K., Prentice, I.C., Saarse, L., Sevastyanov, D.V., Volkova, V.S., Zernitskaya, V.P., 1998. Present-day and mid-Holocene biomes reconstructed from pollen and plant macrofossil data from the former Soviet Union and Mongolia. Journal of Biogeography 25, 1029-1053.

Thiede, J., Suess, E., 1983. Coastal Upwelling. New York: Plenum, 610 pp.

Thompson, L.G., Mosley-Thompson, E., Davis, M.E., Lin, P-N., Henderson, K.A., Cole-Dai, J., Bolzan, J.F., Liu, K-B., 1995. Late Glacial Stage and Holocene tropical ice core records from Huascaran Peru. Science 269, 46-50.

Valentin, J.L., 1984a. Analyses des paramètres hydrologiques dans la remontée de Cabo Frio (Brésil). Marine Biology 82, 259-276.

Valentin, J.L., 1984b. Modeling of the vertical distribution of marine primary biomass in the Cabo Frio upwelling region. Ciência e Cultura 44, 178-183.

Versteegh, G.J.M., 2005. Solar forcing of climate 2: Evidence from the past. Space Science Reviews 120, 243-286.

Wainer, I., Prado, L.F., Khodri, M., Otto-Bliesner, B., 2014. Reconstruction of the South Atlantic Subtropical Dipole index for the past 12,000 years from surface temperature proxy. Scientific Reports 4, 5291. doi: 10.1038/srep05291,

Wang, H., Lui, H., Cui, H., Abrahamsen, N., 2001. Terminal Pleistocene/Holocene paleoenvironmental changes revealed by mineral-magnetism measurements of lake sediments for Dali Nor area, southeastern Inner Mongolia Plateau, China. Palaeoclimatology Palaeoecology 170, 115-132.
Wanner, H., Beer, J., Bütikofer, J., Crowley, T.J., Cubasch, U., Flückiger, J., Goosse, H., Grosjean, M., Joos, F., Kaplan, J.O., Küttel, M., Müller, S., Prentice, I.C., Solomina, O., Stocker, T.F., Tarasov, P., Wagner, M., Widmann, M., 2008. Mid- to late Holocene climate change - an overview. Quaternary Science Reviews 27, 1791-1828.

Wanner, H., Brönnimann, S., Casty, C., Gyalistras, D., Luterbacher, J., Schmutz, C., Stephenson, D.B., Xoplaki, E., 2001. North Atlantic Oscillation - Concepts and studies. Surveys in Geophysics 22, 321-382.

Wooster, W.S., Bakun, A., McLain, D.R., 1976. The seasonal upwelling cycle along the eastern boundary of the North Atlantic, Journal of Marine Research 34, 131-141.

Ybert, J.P., Bissa, W.M., Catharino E.L.M., Kutner, M., 2003. Environmental and sea-level variations on the southeastern Brazilian coast during the Late Holocene with comments on prehistoric human occupation. Palaeogeography Palaeoclimatology Palaeoecology 189, 11-24.

Yiou, P., Fuhrer, K., Meeker, L.D., Jouzel, J., Johnsen, S.J. and Mayewski, P.A. 1997. Paleoclimatic variability inferred from the spectral analysis of Greenland and Antarctic ice core data. Journal of Geophysical Research 102, 26441-26454.

Zazo, C., Goy, J.L., Lario, J., Silva, P.G., 1996. Littoral zone and rapid climatic changes during the last 20000 years: the Iberia study case. Zeitschrift für Geomorphologie 102, 119-134.

Zembruscki, S.G., 1979. Geomorfologia da margem continental sul brasileira e das bacias oceânicas adjacentes. In: Chaves, H.A.F. (ed.), Geomorfologia da Margem Continental Brasileira e das Bacias Oceânicas Adjacentes, Série Projeto REMAC, PETROBRAS-CENPES-DINTEP Brasil 7, 129-177. 